\title{
La expulsión de los judíos de Orán en 1669
}

\author{
Juan A. SÁnchez BelÉn *
}

\section{INTRODUCCIÓN}

En 1669 los judíos oraneses son expulsados por los españoles. El acontecimiento, a pesar de sus trascendencia indudable, carece de estudios pormenorizados, limitándose los especialistas a dar una breve noticia y en algunos casos a establecer erróneamente la fecha del suceso en 1667, cuando Amador de los Ríos, a quien se cita y sigue, escribió únicamente que en dicho año el marqués de los Vélez, don Fernando Joaquín Fajardo de Requesens y Zúñiga, propuso el destierro de los judíos, pero sin mencionar cuándo se produjo ${ }^{1}$. Julio Caro Baroja, erudito como pocos, rectifica el error y nos ofrece en unas cuantas páginas una sinopsis de lo acaecido utilizando la obra de un autor coetáneo proclive al gobernador del presidio, pero se abstiene de contrastar la veracidad de lo escrito con documentos de la época que se custodian en el Archivo General de Simancas y en el Archivo Histórico Nacional ${ }^{2}$. Henry Kamen a su vez sintetiza la aportación de Caro Baroja, incorporando algún que otro dato extraído de un informe del marqués de los Vélez ${ }^{3}$. Sólo Jonathan I Israel contribuye a mejorar nuestro conocimiento sobre el tema en su estudio dedicado a los judios que residían en los presidios españoles

* UNED.

AMADOR DE los Ríos, J., Historia social, politica y religiosa de los judíos de España y Portugal. Madrid 1973, pág. 828; Dominguez OrTız, A., Los judeoconversos en España y América. Madrid 1978, pág. 102; BLÁzQUez Miguel, J., El tribunal de la Inquisición de Murcia. Murcia 1986, pág. 268.

2 Caro Baroja, J., Los judíos en la España Moderna y Contemporánea, t. I. Madrid 1978, págs. 230-233. La fuente utilizada es SOTOMAYOR y VALENZUELA, Luis Joseph, Breve relación y compendioso epitome de la general expulsión de los hebreos de la ludería de la ciudad de Orán, Biblioteca Nacional (BN), Varios, caja $154, n .{ }^{\circ} 40$. Impreso de 22 folios en $4 .{ }^{\circ}$ sin pie de imprenta y sin fecha. Hay otro ejemplar en la sección de Raros con el n. ${ }^{\circ} 5.250$.

3 Kamen, H., La España de Carlos II. Madrid 1980, págs. 492-493. 
del norte de África ${ }^{4}$. Esta parquedad de trabajos científicos nos ha impulsado a elaborar el que ahora presentamos. En él se intentarán esclarecer los móviles (políticos, económicos y religiosos) que condujeron a doña Mariana de Austria, madre de Carlos II y regente del reino en la menor edad de su hijo, a promulgar el decreto de expulsión, así como analizar los medios empleados para ejecutarla y confirmar o desmentir ciertas aseveraciones acerca del rigor usado por las autoridades militares, en particular por don Fernando Joaquín Fajardo, contra esta minoría en el instante de abandonar la plaza y partir hacia otros reinos donde rehacer su vida ${ }^{5}$.

\section{ANTECEDENTES DE LA EXPULSIÓN}

La comunidad judía de Orán, diezmada en 1509 tras la conquista de la ciudad por el cardenal Cisneros a cinco casas e incrementada después por el emperador Carlos $V$ a catorce, para irse expandiendo en el transcurso de la centuria, comenzó a temer por su existencia desde finales del siglo XVI, no obstante su compromiso manifiesto con los españoles, demostrado en infinidad de ocasiones. El aldabonazo primero lo marcó el bando de expulsión promulgado el 13 de junio de 1591 por el marqués de Cardona. Ignoramos por el momento las razones que propiciaron tal medida ni las que hubo para anularlo o dejarlo en suspenso ${ }^{6}$. Unos años más tarde, el 25 de enero de 1597, se ordena al gobernador, marqués de Alcaudete, desterrarlos - iincidió en ello la visita realizada en 1596 por una comisión nombrada en Madrid? ${ }^{7}$-, si bien tampoco se llevó a cabo gracias al Consejo de Guerra que, el 22 de enero de 1599, representó al soberano el perjuicio que dicha resolución podía acarrear a la Corona, especialmente porque los hebreos, actuando de intermediarios entre el mundo islámico y España, mantenían un comercio floreciente de

"ISRAEL, Jonatham I, "The Jews of Spanish North Africa, 1600-1669", Transactions of the Jewish Historical Society of England, XXVI, 1979, págs. 71-86. Algunos datos de este artículo los incluye en su libro European Jewry in the Age of Mercantilism, 1550-1750. Oxford 1985, págs. 112 y 157-158. (Hay traducción al castellano en ediciones Cátedra, Madrid, 1992), págs. 139, 187-188.

5 AMADOR DE LOS Ríos, J., Op. cit., pág. 828. Sería este mal trato del gobernador el que daría paso a un escrito de los judíos oraneses desde Liorna contra su persona.

${ }_{6}$ iSe produjeron enfrentamientos entre judíos y cristianos a raíz de haberse incrementado en 1589 los oficios municipales de la ciudad? ¿Se desataron incidentes a causa de la predicación de la Bula de Cruzada en 1591? Sobre estos pormenores, ULLOA, Modesto, La hacienda real de Castilla en el reinado de Felipe II. Madrid 1977, págs. 590 y 653.

7 Thompson, I. A. A., Guerra y decadencia. Gobierno y administración en la españa de los Austrias, 1560-1620. Barcelona 1981, pág. 75. 
mercancias y de esclavos que, sin su concurso, desaparecería, aunque tal vez primase en el ánimo de este organismo la oferta de algún donativo por parte de la judería -en la consulta mencionada se alude a la visita de una delegación procedente de Orán encabezada por Isaac Cansino ${ }^{8}$-, o su disposición a sufragar las necesidades de la tropa allí acuartelada, desprovista a menudo de vestidos y alimentos ${ }^{\circ}$. Sea como fuere, lo cierto es que los judios oraneses obtuvieron un respiro en sus temores a lo menos hasta 1621, año en el que se plantea la conveniencia de expulsarlos o, si no, de reducir su número, considerado excesivo por el Consejo de inquisición. También ahora el Consejo de Guerra salió en su defensa, disuadiendo al monarca de aplicar esta medida, en parte porque la población hebrea no era tal que hiciese peligrar la seguridad del presidio $y$, sobre todo, porque su presencia era imprescindible en tanto en cuanto que su actividad mercantil permitía contactar con los árabes e indagar sus intenciones bélicas, sin desdeñar la capacidad crediticia que tenían para financiar los gastos del ejército cuando se demoraba el envío del dinero consignado por la Corona:

"en diversas ocasiones apretadas de necesidad que se ofrecieron, hubieran padecido mucho las plazas (Orán y Mazalquivir) si ellos no las hubieran socorrido con bastimientos y gruesas sumas de dinero que habian prestado, con que se reparó y entretuvo la gente, a la cual hacian ordinarias ayudas, de manera que con ellas podían sobrellevar la dotación de las pagas" ${ }^{10}$.

Durante el valimiento del Conde-Duque de Olivares la participación de la judería de Orán en las finanzas castellanas, aunque sólo fuera a nivel local, no debió de ser despreciable ${ }^{11}$. El vicario don Pedro Cantera Vaca, en su Relación de 1636 ó 1637, menciona los muchos servicios pecuniarios y de otra índole prestados por Jaho Çaportas, cuya generosidad no

8 Estos detalles se han extraído de una consulta celebrada en 1659 en la posada del inquisidor General con vista a tratar de expulsar a los judios oraneses. Ver Archivo Histórico Nacional (AHN), Estado, legajo (leg.) 1.749. Según J. 1. Israel, en la década de 1580 Isaac Cansino fue requerido por Felipe II para tratar la incorporación de Ceuta y Tánger (op. cit., pág. 72).

THOMPSON, 1. A. A., op. cit., pág. 95. Sobre la organización del abastecimiento de Orán hay interesantes referencias en esta obra, págs. 255,274 y 283 . En los años $1560-1562$ la provisión para el presidio era de 50.000 ducados, incluida Melilla. En 1584-1585 sólo para la guarnición se requerian 69.000 ducados; en 1589 la cifra se eleva a 83.000 ducados; y en 1597 se sitúa en 143.565 ducados (junto con el Peñón y Melilla). Ver UlLOA, M., op. cit., págs. 105106.

AHN, Estado, leg. 1.749. Consulta de Junta de Teólogos de 1659

ISRAEL, J. I. op. cit., pág. 76 
se circunscribió a estas ayudas, pues con frecuencia sufragó misas por algunos cristianos amigos suyos fallecidos, aun cuando no sabemos si ello obedecía a un carácter magnánimo o a un ardid para no ser acusado de partidista, dada la buena acogida que dispensaba en su casa a los judíos y árabes en tránsito por la ciudad ${ }^{12}$. Otro insigne compatriota suyo, Jacob Cansino, también figura como un valioso aliado de la Monarquía española desde 1623 cuando menos, año en el que el Consejo de Estado le concede permiso para instalarse en la Corte a fin de comunicar determinados informes confidenciales, residiendo en Madrid en 1637 en la calle del Olivo, con licencia del Consejo de la Inquisición para poder hablar con cualquier persona, aunque fuese sospechosa en materia de fe, y conservar sus costumbres y su indumentaria ${ }^{13}$. Las autoridades eclesiásticas, sin duda, tuvieron que sentirse alarmadas por la presencia en España de este personaje, a quien en 1628 la Inquisición de Murcia había detenido, procesado y sancionado, junto a su hijo Abraham, por tener y leer el Talmud, obra prohibida por la iglesia católica dado su contenido antitrinitario ${ }^{14}$. No es aventurado suponer entonces que el Santo Oficio o eclesiásticos celosos de la ortodoxia fuesen los instigadores del rumor que circulaba en la Corte, recogido en sus Memorias por Matías de Novoa, ayudante de cámara de Felipe IV, acerca de la pretensión de los hebreos oraneses de establecerse en Madrid, de la que se hace eco también el vicario don Pedro Cantero en su Relación:

\footnotetext{
12 Jiménez de Gregorio, Fernando, “Relación de Orán por el vicario don Pedro Cantera Vaca (1631-1636)", Hispania, LXXXV, 1962, págs. 81-117. La referencia en la pág. 98. Sobre los servicios prestados por esta familia a la Corona, ISRAEL, J. I., op. cit, págs. 72-73.

13 Elulot, J. H., El Conde-Duque de Olivares. El político en una época de decadencia, 5. ${ }^{\text {a }}$ ed. Barcelona 1991, pág. 305; CARo BAROJA, J., Los judíos..., II, pág. 123 y uLa sociedad criptojudía en la Corte de Felipe IV", Inquisición, brujeria y criptojudaismo, 3. ${ }^{\text {a }}$ ed. Barcelona 1974, pág. 64; Yerushalmi, Yosef Hayim, De la Corte española al guetto italiano. Marranismo y judaismo en la España del siglo XVII. El caso de Isaac Cardoso. Madrid 1989, pág. 96. ISRAEL, J. I., op. cit., págs. 74-75.

14 Blázouez Miguel, J., op. cit., págs. 140-141. En la consulta de la Junta de 1659 donde se trató la expulsión de los judíos de Orán se aduce como un argumento sólido para realizarse ula ingratitud, ceguera, malicia, obstinación y engaño de los judíos y ser tan perjudicial su comunicación; la más perniciosa es la de los judíos talmudistas, que siguen las doctrinas heréticas, sacrílegas y blasfemas contra la Santísima Trinidad, nuestro Señor Jesucristo, nuestra Señora, santos Angeles y Santos, de que están llenos los libros del Talmud ierosolimitano y babilónico y sus comentarios y interpretaciones, los cuales libros y los cabalísticos y los otros que han falsificado las Escrituras están prohibidos por Bulas Apostólicas, y en particular por la de Clemente $8 .^{\circ}$ del año 1593 , y por los expurgatorios del Santo Oficio. Permíteseles la Biblia hebrea, la cual, como dicen algunos doctos, por particular providencia de Dios no está viciada en parte substancial, para que por ella se pueda convencer a los hebreos y paganos y para otros fines reservados a la infinita sabiduría de su divina Magestad" (AHN, Estado, leg. 1.479).
} 
"no ha mucho que algunos de ellos con no poco desahogo pretendian trasladarse no menos que a Madrid y estuvo muy adelante la pretensión, donde si la consiguen harán más daño que provecho" ${ }^{15}$.

La caída del Conde-Duque en 1643 y la animadversión que la mayoría del país manifestaba hacia los conversos portugueses, cualquiera que fuese su status socioeconómico, a quienes se acusaba, con o sin fundamento, de judaizar - muchos, desde luego, eran criptojudíos que cuando salieron de España, como Isaac Cardoso, profesaron abiertamente sus creencias en Amsterdam, Venecia o Liorna ${ }^{16}$ - tuvo que incidir de forma negativa en la ciudad de Orán, donde los gobernadores y los comisarios inquisitoriales enviados por el tribunal de Murcia instaron a la Corona para que adoptase el expediente de desterrar a los judios por los desafueros que cometían contra los signos más reverenciados del catolicismo y por el proselitismo que ejercían, asumiendo así denuncias anteriores, cual la formulada en 1629 por el inquisidor de Murcia ${ }^{17}$. De hecho, en 1646 el marqués de Viana pormulgó al parecer un bando decretando su salida inmediata - simultáneamente, según un corresponsal del padre Pereira, Jacob Cansino fue encarcelado en Madrid por mantener contactos con los marranos portugueses ${ }^{18}$-, pero al final tampoco se llegó a ejecutar la expulsión, que una vez más fue planteada en 1658 por el marqués de San Román aduciendo razones religiosas y políticas, en particular actitudes de infidelidad al monarca, como la que tuvo lugar ese mismo año al haber persuadido las principales familias judias a los árabes para que no abastecieran de trigo al presidio, motivo por el cual se había visto obligado a solicitar grano de España, en una coyuntura marcada por la escasez y la carestía ${ }^{19}$. No obstante, la Junta a la que se encarga el

A. Jiménez de Gregorio, F., op. cit., pág. 102; Codoin, LXXVII, pág. 380; Dominguez Ortiz, A. Los conversos de origen judio después de la expulsión. Madrid 1955, págs. 336-338; LEA, dios..., II, págs. 49-51.

16 Aparte del libro ya citado de Yosef Hayin Yerushalmi, ver MECHOULAN, H., Hispanidad y judaismo en tiempos de Espinoza. Salamanca 1987, págs. 31-34; CARo BAROJA, J., Los judíos..., II, págs. 69-75 y 79-150 y 189-225; BOYAGIAN, James C., Portuguese Bankers at the Court of Spain, 1626-1650. New Jersey 1983, págs. 103-132; BroENs, Nicolas, Monarquía y capital mercantil: Felipe IV y las redes comerciales portuguesas (1627-1635). Madrid 1989, págs. 50-72.

17 Blazquez Miguel, J., op. cit., págs. 267-271. Contra la acusación de proselitismo y profanación de imágenes católicas por parte de los judios se pronuncia Isaac Cardoso en su libro Las Excelencias de los Hebreos (1679). Ver Yerushalmi, Y. H., op. cit., págs. 238-242.

18 Memorial Histórico Español, XVIII. Madrid 1961-1965, pág. 420.

19 La situación agrícola en Andalucía, por lo menos, no fue boyante en 1658, como se desprende de los diezmos de Carmona, Écija y arzobispado de Sevilla, así como de la evolución de los precios, que en la provincia de Sevilla pasa de 25 reales la fanega en 1657 a 34 y medio 
estudio de esta propuesta y de otras análogas formuladas en el pasado no encontró causa justificada que aconsejara poneria en práctica, haciéndolo constar en la consulta de 10 de octubre de 1659: por un lado, las actuaciones de la Corona en esta materia habían sido contradictorias, aprobando y suspendiendo poco después el destierro; por otra parte, los informes recibidos del tribunal del Santo Oficio de Murcia mencionaban dos casos de renegados cristianos, pero no había constancia en los procesos incoados que hubiesen sido pervertidos o inducidos a judaizar por los hebreos ${ }^{20}$; finalmente, atribuye a la dejadez de las autoridades eclesiásticas el que los judíos no abandonen sus prácticas religiosas y, lo que es peor aún, que cultiven la lectura del Talmud y demás libros proscritos, debiéndose velar en la enseñanza de la doctrina cristiana y en la observancia de la Bula de Gregorio XIII del año 1584, donde se ordenaba predicarles «un día cada semana por un predicador católico y que, si se puede hallar, sepa la lengua hebrea" ${ }^{21}$. Por todo esto sugiere en conclusión que antes de adoptarse el destierro conviene averiguar: $\left.1 .^{\circ}\right)$ si los judíos persuaden a los católicos a abrazar su religión o el mahometismo; $\left.2 .^{\circ}\right)$ si injurian en público o hacen irrisión de los dogmas de la fe católica y de sus imágenes; $3 .^{\circ}$ ) si impiden a sus correligionarios instruirse en la doctrina cristiana, y $4 .^{\circ}$ ) si por estar muy poblada la judería se puede temer una sedición o entregar la plaza al enemigo. Sólo cuando se demuestre con pruebas suficientes la mala voluntad de la comunidad hacia

en 1658 y a 42 dos tercios en 1659. A su vez la alhóndiga de dicha ciudad registra en 16571658 el precio de la fanega de trigo en 25 reales y en 1658-1659 en 40 reales. En el arzobispado de Cartagena también desciende el diezmo de trigo y la cebada en el período 1658-1659, al igual que en Yecla. Ver PONSOT, Pierre, Atlas de Historia Económica de la Baja Andalucía (siglos XVI-XIX). Sevilla 1986 y PÉrez PICAzo, M. a T. y Lemeunier, G., El proceso de modernización de la región murciana (siglos XVI-XIX). Murcia 1984, Apéndice, gráficos 3 y 4 . Para el enfrentamiento del marqués de San Román con los Çaporta, IsRAEL, J. I., op. cit., pág. 76.

2o Según Bláquez Miguel que ha estudiado la actuación del Santo Oficio en Orán, entre 1560 y 1700 el criptojudaísmo no fue un problema grave en la ciudad, ya que sólo aparecen catorce casos, lo que representa un 7 por 100 del total de los procesos incoados. Más importancia tuvieron los moriscos, pues se elevan a 115 los expedientes formados contra ellos, de los cuales 68 se produjeron en las dos primeras décadas del siglo xvII, las más activas desde el punto de vista inquisitorial (pág. cit., págs. 267-271).

21 La ingenuidad de la Junta respecto a la enseñanza de la doctrina cirstiana a los judíos como paso previo para su ulterior conversión queda reflejada magníficamente en la Relación del vicario Don Pedro Cantero Vaca: "Siempre que cualquier predicador cristiano les va a predicar a la Sinagoga suspenden el rezo y la oyen, pero no hacen caso de lugares de Santos si no sólo de la Escritura, y cuando algún predicador les quiere predicar en público en alguna iglesia comunícalo primero con el vicario, el cual despacha su mandamiento con pena pecuniaria, y para tal día y en tal iglesia acudan a oír la palabra de Dios. Y aunque de mala gana van por el temor de la pena, y se les da lugar junto al púlpito, descubiertos en pie, y acabado el sermón se vuelven a sus casas. Son raros los que se convierten en nuestro tiempo. En el mío fueron seis" (JIMÉNEZ de Gregorio, F., op. cit., pág. 100). 
la religión católica y se sospeche con fundamentos sólidos que pueden intentar algo contra la tropa y la población española, entonces será prudente, y hasta aconsejable, que se les expulse, lo cual, en todo caso, se ejecutará sin ocasionar los «agravios, vejaciones y extorsiones que se les ha hecho en muchas expulsiones", procurándose al mismo tiempo que vayan a algún país católico, donde «no se pierda la esperanza de su conversión», siempre que no sea "de enemigos, a quienes con su entrada y caudal pueden dar mayores fuerzas y noticias" ${ }^{22}$.

Entre 1658 y 1667 no se vuelve a plantear por ninguna autoridad civil - eclesiástica una acción contra los judíos oraneses. Esto no implica, sin embargo, que fuesen aceptados por los españoles, continuamente al acecho de cualquier desliz cometido contra la defensa de la plaza o la religión católica. Un suceso acaecido en 1663, seguramente inventado o provocado, los situará una vez más en el centro de mira del gobernador. Según el marqués de los Vélez, en carta escrita al padre Nithard en 1667, aconteció que durante la Semana Santa de aquel año varios judíos cogieron a una mujer llamada María y la llevaron en hombros, como si de una procesión se tratara, con sonajas, bailes y algazara por las calles de la judería, celebrando con risas el espectáculo cuantos lo veían, el cual finalizó arrojando a la mujer en un rincón donde «la escupieron y oprobiaron todos, diciendo tratarian así a los que los cristianos llamaban Madre de Dios, a serles posible" ${ }^{23}$. Los hechos no debieron de ser tales 0 , cuando menos, los autos levantados por el comisario del Santo Oficio de la ciudad y por el vicario eclesiástico -éste fue el primero en proceder a fin de apaciguar a la milicia y a la población que "se tumultuó para pasarlos a cuchillo"-, remitidos a Madrid por el Tribunal de Murcia en 2 de octubre ${ }^{24}$, no bastaron para convencer a la Suprema del delito achacado, pues se ordenó soltar a las personas detenidas sin aplicarles castigo alguno, cosa que desagradó al gobernador, entre otros ${ }^{25}$. Aunque el marqués de los Vélez refiere en otro informe a la reina un suceso de caractísticas similares ${ }^{26}$ no parece ser que durante su mandato se produjesen desa-

22 AHN, Estado, leg. 1.749. Consulta de la Junta especial sobre la expulsión de los judios, 10 de octubre de 1659. Los integrantes de esta comisión eran el Inquisidor General, el cardenal Don Pedro Aragón, el padre confesor, fray Juan Martínez, el maestro fray Francisco Gamboa, electo obispo de Coria y el maestro fray Nicolás Baptista.

23 Sotomayor y ValenzUela, Luis Joseph de, Breve Relación y compendioso Epítome de la General Expulsión de los hebreos..., 1670, fols. 4-4v; CARO BAROJA, J., Los judíos..., I, págs. 232-233.

24 AHN, Inquisición, leg. 2.825.

25 Sotomayor y Valenzuela, L. J., op. cit., fol. 4V.

26 AHN, Estado, leg. 1.749. Carta del marqués de los Vélez, 23 de septiembre de 1668. 
catos contra la religión católica. Así lo manifiesta su confesor y comisario del Santo Oficio en Orán en carta de 20 de abril de 1668: "cumpliendo con la obligación del oficio he aplicado todo mi cuidado a inquirir el modo de vivir de los hebreos y [...] no he encontrado en él disonancia a nuestra santa fe católica" ${ }^{27}$. De cualquier manera, hacia estas fechas el sentimiento antisemita estaba ya tan arraigado entre los oraneses que un mero pretexto dará ocasión a que en Madrid se decrete el destierro de los judíos y éste no fue otro que la provisión del oficio de intérprete de la lengua árabe al fallecer Jacob Cansino en 19 de septiembre de 1666. Poco podía sospechar este insigne personaje que tanto procuró el lustre de su familia sirviendo a la Corona española y al Conde-Duque de Olivares, a quien dedicó la traducción al castellano del libro de Moses Almonsino, Extremos y Grandezas de Constantinopla, editado en Madrid en 1638, que su muerte marcaría el principio del fin de la judería de Orán ${ }^{28}$.

\section{GÉNESIS DEL DECRETO DE EXPULSIÓN}

El origen del decreto de 31 de octubre de 1668 ordenando la salida de los judíos oraneses se encuentra en una carta de don Fernando Joaquín Fajardo, marqués de los Vélez, fechada el 22 de octubre de 1666, notificando a doña Mariana de Austria haber quedado vacante uno de los dos oficios de intérprete de la lengua árabe, el que había desempeñado hasta entonces Jacob Cansino - el otro, el de intérprete mayor, lo ejercía don Gil Fernández de Navarrete ${ }^{29}$ - y lo preciso que era nombrar persona adecuada. Entre los candidatos menciona a Samuel y Salomón Çaportas pero desconfía de ellos por su ambición desmedida y su negativa a cum-

27 AGS, Guerra Antigua, leg. 2.189. Carta de fray Pedro Angel, 20 de abril de 1668.

28 ELLIOTT, J. H., op. cit., pág. 305; Yerushalmi, Y. H., op. cit., págs. 96-97.

29 AHN, Estado, leg. 1.749. Carta del marqués de los Vélez, 22 de octubre de 1666. En este documento se describe minuciosamente la pugna que se suscitó entre Jacob Cansino y Jaho Caportas por ostentar el título de intérprete de árabe. El proceso, resumido, es el siguiente. A la muerte de Arron Cansino, el marqués de Flores Dávila, gobernador de Orán, nombra para el cargo a Jaho Çaportas en 13 de junio de 1633, siendo ratificado por Real Cédula de 21 de mayo de 1634 pero sólo a título de "entretenido». Jacob Cansino, por su parte, trata de conseguir el empleo en propiedad como lo había desempeñado su hermano y el 13 de noviembre de 1636 logra su objetivo. Esto va a suponer una serie de litigios entre ambos pretendientes de tal modo que en 1643 una Real Cédula dirigida al marqués del Viso le ordena consumir uno de los dos oficios. No concluyeron aquí las disensiones y así, tras someterse la cuestión a una Junta Particular designada a dicho efecto por Felipe IV, éste a consulta suya promulga una Real Cédula, su fecha 16 de junio de 1646, por la cual se jubila a Jaho Çaportas, prohibiéndole que en adelante presente memorial alguno en apoyo de su pretensión al oficio, con lo que queda zanjado definitivamente el litigio. La visión que Jacob Cansino ofrece de este contencioso se puede ver en su traducción de Extremos y Grandezas de Constantinopla. Madrid 1638. 
plir ciertas órdenes de los gobernadores que le precedieron ${ }^{30}$. Aspiran también al empleo los hijos de Jacob Cansino, en cuya familia se ha venido transmitiendo desde antiguo. Por último, señala la opinión de algunos españoles del presidio, partidarios de privar a los judios del cargo, habida cuenta de que la lengua árabe la dominan ya muchos soldados y civiles lo que no sucedía en el pasado. El marqués de los Vélez, sin embargo, rechaza esta alternativa: "lo uno, por el riesgo que hay en que aunados los dos lenguas beneficien su inteligencia, lo cual no parece facil en la distancia que hay de un hebreo a un cristiano; y lo otro, porque como el hebreo vive siempre temeroso del castigo [...] solicita con la lisura acreditarse para su conservación". En consecuencia, recomienda que el nombramiento recaiga en un judío, concretamente en Hayen Cansino, hijo del anterior intérprete, y esto porque ha demostrado con creces estar capacitado para el oficio, pues desde el 18 de julio de 1638 , por Real Cédula de Felipe IV, venía sustituyendo a su padre cuando caía enfermo o se ausentaba - sobre este particular discrepa fray Pedro Angel, comisario del Santo Oficio, más proclive a la familia Çaportas, a la que juzga mejor preparada y más atenta «a lo tocante a nuestra religión» ${ }^{31} \ldots$, pero sobre todo porque en su persona se recompensan los servicios de Jacob Cansino a la Corona, cuyos desvelos le condujeron a la ruina económica, sumiendo en tal miseria a su esposa e hijos «que si yo a cuenta de el sueldo que venció no les hubiera hecho dar un poco de trigo [...] no hubieran comido" ${ }^{32}$. No obstante, por si acaso desagrada su propuesta en Madrid o la reina prefiere designar a un español, menciona a los capitanes don Alonso de Angulo Montesinos y don Diego Merino como los más idóneos para desempeñar el cargo de intérprete de árabe por sus méritos e inteligencia.

Frente a lo que sostiene don Luis Joseph de Sotomayor en su opúsculo acerca de la expulsión de los hebreos de Orán, el marqués de los Vélez no se mostró al principio partidario de que el cargo de intérprete recayese en un cristiano ${ }^{33}$. Esto no significa, empero, que confraternizase con la

3o Jacob y Samuel Çaportas, escribe el marqués de los Vélez, no se comportaron con el mismo celo que su padre en servir a los gobernadores de Orán, portándose "con tal ambición y soberbia que obligó al marqués de Astorga a procesarlos [...] y a desterrarlos de aquí, haciéndoles harta gracia en no pasar a mayor demostración, y creo, según las noticias de los que conozco y las muestras de los que comunico, que siempre que vuelvan a tener mano olvidarán el castigo' (AHN, Estado, leg. 1.749. Carta del marqués de los Vélez, 22 de octubre de 1666).

31 AGS, Guerra antigua, leg. 2.189. Carta de fray Pedro Ángel, 20 de abril de 1668.

32 AHN, Estado, leg. 1.749. Carta del marqués de los Vélez, 22 de octubre de 1666.

33 SotomaYor Y VAlenzUELA, L. J., op. cit., fol. $1 \mathrm{v}$. Es muy significativo al respecto que no reproduzca la carta del marqués de los Vélez del 22 de octubre de 1666, cuando inserta otras posteriores. 
comunidad judía. Buena prueba de lo que opinaba al respecto son sus cartas de 27 y 28 de marzo de 1667, una dirigida al padre Nithard y otra a doña Mariana de Austria, en respuesta a un despacho de 30 de noviembre de 1666 donde se le solicitaba informase de los impedimentos que podían surgir de nombrar a un español para el empleo. En estos escritos, don Fernando Joaquín Fajardo plantea sin ambigüedad su parecer aprovechándose de esta ocasión única que se le brinda: la medida no es recomendable políticamente ya que los judíos, despojados del oficio, "es de temer, y aun probablemente puede creerse, que todas las noticias que conservan de las materias de Africa y correspondencia con los alarbes la conviertan en conocido daño y perjuicio de estas armas"; cosa muy distinta es que al tiempo de privarles del empleo se les arroje de la ciudad, lo cual "no sólo no tiene inconvenientes, pero encierra conocidas conveniencias al servicio de V. Magd» ${ }^{34}$.

Ambas misivas tuvieron que influir en la reina, mujer de acendradas creencias religiosas pero de cortas luces, y en el confesor e inquisidor general, padre Everardo Nithard, puesto que el 12 de mayo se ordena al marqués de los Vélez que exponga su opinión, no ya sobre los perjuicios de designar a un cristiano para el puesto de intérprete de árabe, sino de las ventajas o inconvenientes que pueden derivarse de mantener la judería oranesa. En su escrito, el gobernador intenta impresionar el ánimo regio indicando que no existe motivo alguno, ni político ni económico y menos aún militar, -están organizados en compañias y disponen de armas en previsión de un posible ataque de los árabes, lo que resulta muy peligroso porque pueden ponerse al lado del enemigo-, para que se permita su presencia en la plaza, siendo por el contrario facilísima su expulsión, entre otras razones:

"porque no tienen bienes raices algunos [...] sino sólo las casas de su habitación, y éstas con cargas de muchos censos en favor de cristianos, y que comprándolas por cuenta de V.M. las que parecieren bastantes se formará en ellas un cuartel para la habitación de soldados, de que se necesita mucho, y las demás las comprarán los vecinos a porfía porque viven en penosa estrechura [...] y lo que es más, se sacará de raiz esta sinagoga, padrastro tan pernicioso en contraposición de esta debota iglesia, donde al tiempo que se celebran los divinos oficios pueden oirse los alaridos de esta perversa gente en la perfidia de su réprobo culto" ${ }^{35}$.

34 AHN, Estado, leg. 1.749. Carta del marqués de los Vélez, 28 de marzo de 1667. La carta al padre Nithard con fecha 27 de marzo en SoTomayon, op. cit., fols. $2-6 \mathrm{v}$.

${ }_{35}$ Ibidem. Carta del marqués de los Vélez, 8 de junio de 1667. ISRAEL, J. I. traza asimismo una sucinta descripción del proceso iniciado por el marqués de los Vélez para expulsar a los judíos (op. cit., pág. 82). La hipoteca de las casas de los judios a que se alude en este escrito 
Al plantear la ausencia de obstáculos para expulsar a los judíos sin consecuencias demasiado graves para los afectados, pues sus escasas pertenencias están hipotecadas a los cristianos, y omitir cualquier conveniencia para el Estado, lo que es por sí sólo muy significativo de la parcialidad del marqués de los Vélez, se está dando el golpe de gracia a la judería. Desde este momento la reina y el padre Nithard tienen decidido su destino. Ahora no resta sino convencer al Consejo de Estado y a ello se consagran. Antes, sin embargo, se pulsa el parecer del Consejo de Guerra, organismo que en el pasado había apoyado, de una manera u otra, a los hebreos oraneses. En su consulta de 15 de julio de 1667 el Consejo de Guerra se pronuncia favorablemente a que el oficio de intérprete de la lengua árabe recaiga en un español y se sorprende, "por cosa muy extrema y mal consentida», que los judíos posean armas, aconsejando se escriba al gobernador dándole a entender que proceda de inmediato, pero con cautela y sin agraviarles, a recogerlas. Por lo que respecta al destierro, el Consejo simplemente juzga oportuno someter este asunto a un organismo competente, donde se trate "con todo secreto, examinándose con toda atención las razones que alega el marqués y las que en otras ocasiones se hubieren propuesto" ${ }^{36}$. Solicitada la opinión del padre Nithard en 9 de octubre, éste considera asimismo necesario remitir la correspondencia de don Fernando Joaquín Fajardo y la consulta del Consejo de Guerra, junto con los documentos que haya sobre este particular, al Consejo de Estado para que proponga lo más pertinente al servicio de la Monarquía ${ }^{37}$, lo cual así se ejecuta, aunque lo lógico hubiera sido someter la cuestión a la Junta de Gobierno instituida por Felipe IV en su testamento para asesorar a la reina durante la minoridad de su hijo Carlos II en asuntos políticos graves, de suerte que se vulnera una de las cláusulas esenciales del legado de aquel soberano, actitud comprensible si tenemos en cuenta que la Junta casi nunca aprobó las propuestas del valido, cuya posición en este tribunal fue siempre insegura ${ }^{38}$. El Consejo

tal vez proceda del préstamo concedido a la Corona en 1656 por la comunidad. En cualquier caso, confirman el endeudamiento los xeques Samuel Çaportas y Abrahan Cansino en su memorial del 20 de mayo de 1668 (AHN, Estado, leg. 1.749).

${ }_{36}$ Ibidem. Consulta del Consejo de Guerra, 15 de julio de 1667.

3r Ibidem. Carta del padre Nithard, 13 de octubre de 1667

38 No hay unanimidad entre los historiadores al abordar la influencia de la Junta de Gobierno instituida por Felipe IV en su testamento en los primeros años de la regencia de doña Mariana de Austria. KAMEN, H. (La España de Carlos II. Barcelona 1980, pág. 52) y Barrios, F. (El Consejo de Estado de la Monarquía Española, 1521-1812. Madrid 1984, pág. 152) sostienen que la reina actuó en todo momento bajo su control, sometiendo a dicho organismo los asuntos de gobierno para que emitiesen su parecer, el cual luego iba al Consejo de Estado desde donde se ejecutaba lo resuelto. Por el contrario, DanviLA y Collado, M. (El poder civil en España, t. II. 
de Estado, después de analizar los papeles recibidos, decide el 14 de enero de 1668 que el expediente sobre la expulsión sea estudiado por una Junta particular reunida en la posada del Inquisidor General, con asistencia de los ministros que la reina designe, incluido uno del Consejo de Guerra "por contener materias dependientes de él»" ${ }^{39}$.

Aunque esta consulta carece de respuesta, lo cierto es que doña Mariana de Austria se atuvo a su dictamen, constituyendo una Junta a dicho efecto presidida por el Inquisidor General, padre Nithard, e integrada por el marqués de Montalbán, del Consejo de Guerra, el maestro fray Francisco de Arcos y don Mateo de Moya. El 28 de enero de 1668 expone su opinión sobre el asunto, la cual, como cabía suponer, fue favorable a la expulsión, debiéndose decretar enseguida y en secreto. El Consejo de Estado, a quien se remite esta consulta, es partidario también de que se lleve a cabo el destierro con sigilo y, sobre todo, bien planificado para no arriesgar la empresa, de tal manera que antes de ejecutarse se tengan previstos los detalles más nimios, comenzando por desarmar a los judíos pero sin causarles recelo, como lo aconseja el conde de Ayala, e indagando a través del marqués de los Vélez, a quien todavía no se comunicará la decisión adoptada, si será necesario enviar alguna gente de guerra en el hipotético supuesto de ordenarse la salida de los hebreos, consultas que en cualquier caso no serán respondidas para no alertar a los afectados que pueden enterarse por medio de sus agentes o amigos instalados en las secretarías ${ }^{40}$. El 28 de abril se escribe al gobernador de Orán solicitando los informes mencionados, pero éste se demora en

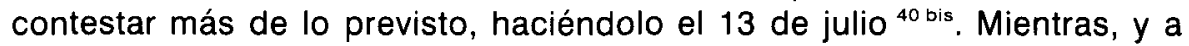
pesar de la cautela del Consejo de Estado, la comunidad judia sospecha que algo se está fraguando contra ella en Madrid, alertada por las noticias que el capitán de caballos, don Andrés de Navarrete, ha divulgado acerca de los interrogatorios que se le hicieron en la Corte sobre la utilidad pública de los hebreos, sus empleos y otros pormenores, así como por los avisos que el veedor del presidio les ha facilitado, por ser, en palabras

Madrid 1885-1886, pág. 214) afirma que la regente siempre prefirió el Consejo de Estado en lo relativo al asesoramiento de asuntos políticos de envergadura. En el caso que nos ocupa, la expulsión de los judios de Orán, no parece ser que interviniera la Junta de Gobierno. Respecto a los conflictos por competencias suscitados entre este organismo y el Consejo de Estado, Escudero, J. A., “Consultas al Consejo de Estado: trámites irregulares en el reinado de Carlos II", Homenaje al Dr. D. Juan Reglá Campistol, t. I. Valencia 1975, págs. 661-664.

$39 \mathrm{AHN}$, Estado, leg. 1.749. Consulta del Consejo de Estado, 14 de enero de 1668.

40 Ibidem. Consulta del Consejo de Estado, 15 de marzo de 1668. Esta consulta está rubricada solamente por el cardenal Aragón, el conde de Ayala, el Inquisidor General y el marqués de la Fuente.

40 bis Según Sotomayor respondió cuanto antes a esta orden (op. cit., fol. 7). 
del marqués de los Vélez, "su declarado protector en cuanto se les ofrece" ${ }^{41}$. No de otro modo se explica el memorial enviado al Inquisidor General el 20 de mayo por los xeques Samuel Çaportas y Abrahan Cansino, donde se exponen los diversos servicios prestados por la judería a la Corona, participando en el rescate de cristianos cautivos en Argel, denunciando al Santo Oficio el tránsito de "hebreos que en hábito de cristianos pasaban de España para entrar en Berbería", colaborando en la detención de soldados que desertaban de la plaza y contribuyendo en su defensa de los ataques árabes, además de conceder empréstitos cuantiosos al erario, de los cuales aún se les adeudaban sumas considerables. Junto a estos servicios no dudan en señalar los intentos habidos en el pasado para expulsarles sin causa justificada y sólo por instigación de algunos émulos de su riqueza. Concluye el escrito denunciando la amenaza que una vez más se cierne sobre ellos a causa de quienes pretenden obtener el oficio de intérprete de árabe, pues seguros de la dificultad de conseguirlo tratarán con este propósito de desacreditarlos, en lo que proseguirán aun cuando obtengan la merced del empleo, razón por la cual solicitan que

"en cualquier acontecimiento tenga nuestra defensa el lugar que como fidelicísimos (sic) vasallos de S. Magd. merece, sin que el recato de las calumnias sea motivo a desviar nuestros méritos, así en lo tocante al real servicio como en el de la religión xpana, que continuaremos con iguales demostraciones de obediencia durante nuestras vidas» ${ }^{42}$.

Tal prevención, para desgracia de la comunidad judía, fue inútil, como también resultó infructuoso comisionar a Jacob Çaportas el encargo de acudir a la Corte a fin de defender su causa, pues noticiosa la reina de su llegada a Cartagena procedente de Génova ordena taxativamente al gobernador militar de la ciudad, don Carlos Calonne, que le expulse, embarcándole en el primer navío dispuesto a zarpar con destino a Orán, asumiendo así el parecer dado por el marqués de los Vélez y aprobado por el Consejo de Estado, que despachó al de Guerra un decreto en este sentido. El embarque, sin embargo, no llegó a realizarse porque falleció días antes, si bien sus papeles fueron remitidos a sus parientes oraneses con un criado ${ }^{43}$. El fracaso de estas gestiones radicó, en gran medida,

4. Ibidem. Carta cifrada del marqués de los Vélez, 23 de septiembre de 1668.

42 Ibidem. Memorial de Samuel Çaportas y Abrahan Cansino, 20 de mayo de 1668.

43 AGS, Guerra Antigua, leg. 2.189. Carta de don Carlos Calonne, 5 de noviembre de 1668 y leg. 2216. Carta de don Carlos Calonne, 24 de diciembre de 1668. El aviso del marqués de los Vélez sobre la presencia de Jacob Çaportas en Cartagena y su consejo para que se le expulse de la ciudad, impidiéndole que prosiga su viaje hacia Madrid, en AHN, Estado, leg. 
en que el Consejo de Guerra, antiguo valedor de la judería, a pesar de estar representado en la Junta que trataba de la expulsión, no tuvo ninguna oportunidad de abogar en su defensa al quedar relegado a un segundo plano por la reina y el Consejo de Estado. De hecho, no se le volvió a consultar este asunto y ni siquiera estuvo informado de los preparativos para llevar a cabo el destierro, pues éstos se mantuvieron en secreto siguiendo las recomendaciones del gobernador de Orán formuladas en su carta de 13 de junio de 1668, donde exponía las medidas que se debian adoptar sin levantar sospechas: en primer lugar, despachar a los gobernadores de Cádiz, Málaga y Alicante y al virrey de Valencia la orden de que envíen algunos bajeles al presidio con la excusa de abastecerse de trigo - el coste de los fletes correrá a cargo de los judíos expulsados-; en segundo término, y por lo que se refiere al embarque de soldados con los que asegurar la empresa, y cuyo número no deberá ser inferior a 400, que de las levas realizadas se destinen 200 hombres y el resto que lo recluten Lorca, Totana, Mula y Alhama, a las cuales se remitirán los decretos oportunos para que lo ejecuten, lo mismo que al gobernador de Cartagena,

"pretextándoles con haber yo dado a V.Mgd. noticias de que en Argel se prevenía mahala para venir a poner sitio sobre estas plazas y cuarenta bajeles para el mismo efecto, como es cierto me lo ha asegurado un moro confidente, aunque parece que por este año no tendrá efecto" ${ }^{44}$.

El plan de don Fernando Joaquín Fajardo es aprobado unánimemente por los miembros de la Junta el 18 de julio pero encuentra obstáculos en el Consejo de Estado, pues en la consulta de 20 de julio el conde de Peñaranda, que no había participado antes en los debates, opone serios reparos -el dictamen de los demás integrantes es muy revelador: el duque de Sanlúcar no se pronuncia porque la expulsión está ya decidida por la reina y sólo cabe acatar sus designios; el cardenal Aragón y el padre Nithard apoyan lo resuelto por la Junta-, manifestando que aún no se habían esclarecido por completo las razones que indujeron al emperador Carlos $\mathrm{V}$ a permitir el asentamiento de los judios en Orán ni las condiciones estipuladas con ellos para su permanencia en la ciudad y tampoco si éstas habian sido vulneradas. Aparte de estas cuestiones juzga peligrosa la empresa en tanto no se envíen tropas al presidio para reforzar

1.749. Carta de los Vélez, 23 de septiembre de 1668. También alude a ello Sotomayor y VALEN. ZUELA, L. J., op. cit., fol. 10.

${ }_{44}$ AHN, Estado, leg. 1.749. Carta del marqués de los Vélez, 13 de junio de 1668. Resume el contenido del escrito Sotomayor y VALENZUELA, L. J., op. cit., fols. 7-7v. 
su guarnición, ya que se puede producir una alianza de los hebreos con los musulmanes en un intento desesperado por impedir el destierro. Finalmente considera necesario averiguar hacia qué lugar desean trasladarse en el caso de ser expulsados, quizás para negociar su admisión con las autoridades de las plazas elegidas, pues "Liorna $u$ otros lugares semejantes son casa ajena donde no sabemos si los querrán recibir" -con este último aspecto se aviene también el cardenal Aragón- ${ }^{45}$.

Las objeciones del conde Peñaranda retrasan unos meses la ejecución del proyecto al verse la Corona precisada a satisfacer el punto de mayor reparo presentado por el ministro: encontrar motivos que justifiquen el destierro de los judíos oraneses. Cabe suponer que el conde de Peñaranda tuviese escrúpulos éticos a la hora de adoptar una decisión de tanta envergadura, pero nos inclinamos a pensar que en su conducta primó ante todo su experiencia diplomática: había que convencer a las Cortes europeas de que la resolución arbitrada obedecía a razones de Estado y no a una actitud religiosa intransigente del gobierno español. Para dar cumplida respuesta a las cuestiones formuladas por don Gaspar de Bracamonte, la reina expide un despacho a la Junta con el encargo de emitir su parecer al respecto. Ésta sostiene una vez más que no existe ningún privilegio especial otorgado a los judíos para establecerse en Orán, pero aun cuando lo hubiera, y sólo se beneficiasen de él cinco o siete familias, no se debía perpetuar por más tiempo, en parte porque resultaría imposible reducir el número de hebreos a aquellos primeros vecinos y especialmente porque habiéndose multiplicado tanto

“justamente se puede y debe recelar de su poder, y más con la aversión que tienen a nuestra religión, y que con tanta ocasión como les dan las nuevas diversiones que tiene la Monarquía, la poca prevención de la plaza la entreguen a los moros o a los ingleses, que con la vecindad de Tánger y el deseo de ampliar sus fuerzas la quiten a V.M. y las demás que tiene en África. Y habiendo llegado el caso de este justo temor no está V.M. obligada a guardar el contrato o privilegio en perjuicio de nuestra sagrada religión y de la quietud de sus reinos y seguridad de la plaza, antes será de muy grave escrúpulo el tenerla tan aventurada. Con esta suposición no es necesario pasar a averiguar si los hebreos han cumplido o no las condiciones, pues no se funda en ello el sentir de la Junta, sino en la utilidad pública y de la religión” ${ }^{46}$.

De este parecer es también el marqués de los Vélez. En el prolijo informe que remite cifrado con fecha de 23 de septiembre de 1668 indica

45 Ibidem. Consulta del consejo de Estado sobre consulta de la Junta, 20 de julio de 1668.

46 Ibidem. Consulta de la Junta y del Inquisidor General, 16 de septiembre de 1668. 
que sólo ha encontrado una Real Cédula despachada por Fernando el Católico en Burgos a 30 de enero de 1512 autorizando la residencia de tres familias hebreas, una como intérprete de la lengua árabe. No rechaza la posibilidad de que Carlos $V$ autorizase nuevos asentamientos, pero no se ha atrevido a buscar en los libros registro que custodia el veedor por no alertarle, dada la simpatia que manifiesta mostrar hacia la comunidad. En cualquier caso, sostiene que las condiciones establecidas en su momento han sido vulneradas al ascender la población de la judería a 500 personas. Respecto a expulsar a todos exceptuando a las primeras familias no lo juzga posible ni conveniente. En cuanto a la fidelidad a la Corona recoge varios testimonios que la contradicen, así como refiere algún que otro acto contra la religión católica ${ }^{47}$.

El Consejo de Estado, que el 30 de septiembre de 1668 no quiso pronunciarse sobre el dictamen de la Junta hasta no disponer el solicitado al gobernador de Orán, emite su parecer el 13 de octubre sin la asistencia, muy significativa, por otro lado, del conde de Peñaranda. A la vista de ambas consultas resuelve que se decrete el destierro, pues "no sólo no hay motivos para mudar el intento [...] sino antes bien se corroboraran los fundamentos y razones que hay para ello, con que particularmente siendo ya resolución tomada antecedentemente por V.M. no hay que discutir" ${ }^{48}$. Aceptada esta respuesta por la reina, el 31 de octubre de 1668 se comunica al marqués de los Vélez la resolución de expulsar a los judíos. El mismo día se envía un despacho al gobernador de Cartagena ordenándole que en cuanto reciba carta del marqués de los Vélez solicitando tropas se las remita sin demora en las galeras de España al mando del duque del Viso o, si éste aún no ha llegado al puerto, en cualesquiera otras embarcaciones. También el 31 de octubre se escribe al marqués del Viso para que se disponga a cumplir con lo que le ordene el marqués de los Vélez, transportando hacia Oran los soldados que éste juzgue necesarios y en el supuesto de no estar preparados que desembarque la gente de las galeras y las ponga a disposición del gobernador del presidio ${ }^{49}$.

\section{CAUSAS DE LA EXPULSIÓN}

En las páginas precedentes hemos ido exponiendo algunos de los motivos de descontento de las autoridades de Orán, y presumiblemente

47 Ibidem. Carta del marqués de los Vélez, 23 de septiembre de 1668; Soto Mayor y VA. LENZUELA, L. J., op. cit., fols. 8-10. La referencia al despacho de la reina solicitando informes en 22 de agosto de 1688 aparece en el opúsculo antes citado, fol. $7 \mathrm{v}$.

4b Ibidem. Consulta del Consejo de Estado, 30 de septiembre de 1668 y Consulta del 13 de octubre de 1668 .

${ }_{49}$ Ibidem. Despachos de la reina al marqués de los Vélez, al marqués del Viso y al gobernador de Cartagena, 31 de octubre de 1668. 
también de la población cristiana, hacia la comunidad judía. Esos mismos factores son los que se van a tener en cuenta cuando la reina doña Mariana de Austria decida, siguiendo la opinión del padre Nithard y de los consejeros de Estado, decretar la expulsión. En primer lugar influyó el criterio religioso. Para el clero, así como para los habitantes de la ciudad, la existencia de la sinagoga era una provocación y, lo que resultaba más grave, un elemento aglutinador que los hebreos disponían para mantener sus creencias firmemente arraigadas, sin que la acción evangelizadora de los católicos pudiera hacer mella en sus ánimos, más bien al contrario, aparte de que su presencia favorecía, o asi se creía, el que muchos musulmanes e incluso españoles abrazasen la ley mosaica, temor a todas luces infundado, pues fueron esporádicos los casos de renegados cristianos, aunque pudieran haber sido más numeroros dada la asidua correspondencia que mantenian los españoles con los judíos, asistiendo a sus negocios y compartiendo sus fiestas familiares ${ }^{50}$. De todas maneras, tales contactos, presididos por motivos económicos, eran independientes de la animadversión generalizada que, con notables excepciones ${ }^{51}$, les manifestaban los pobladores cristianos de Orán, si bien este sentir estuvo condicionado a menudo por sucesos debidos a la inopia - la estulticia de los clérigos, quienes poco a poco fueron enrareciendo la convivencia, nunca fácil, es cierto, entre ambas comunidades, al provocar con sus actos altercados violentos que ponian en peligro la seguridad de la plaza. Uno de estos enfrentamientos lo refiere el vicario don Pedro Cantero Vaca y aconteció durante su ministerio. Informado de que un judio agonizaba fue a visitarle con el piadoso intento de procurar salvar su alma, covirtiéndole a la fe de Cristo. La muchedumbre congregada en torno al moribundo le impidió llegar hasta él y sólo la amenaza de sanciones pecuniarias ( 50 reales de a ocho) a quienes no le permitiesen acercarse al enfermo pudo facilitarle su intento de allegarse al lecho mortuorio, consiguiendo que la habitación se descongestionara de gente, aunque al tiempo que unos salían por la puerta entraban otros, sobre todo mujeres de la familia, las cuales, con llantos y alaridos, le obstaculizaron de nuevo aproximarse al yacente. Finalmente, viendo que los cristianos comenzaban a arremolinarse traídos por un compañero del vicario que fue a solicitar ayuda, la esposa y un primo del agonizante se arrojaron sobre él y con un cobertor lo asfixiaron en presencia de todos, pues, según testificaron luego, no deseaban que fuera bautizado, "porque apretado de la enfer-

50 Jiménez de Gregorio, F., op. cit., pág. 99.

51 El veedor, por ejemplo, según el marqués de los Vélez. AHN, Estado, leg. 1.749. Carta de 23 de septiembre de 1668 . 
medad [...] si yo le preguntase si quería morir christiano, delirando pudiese disparatadamente, y sin entrar en la pregunta, responder a ella que sí» ${ }^{52}$.

Semejantes injerencias en el vivir cotidiano de los judíos tuvo que originar un profundo malestar entre ellos contra los cristianos, lo cual a su vez, repercutiría en la gobernabilidad del presidio. Recelosos éstos y acosados aquéllos, la sensación de inseguridad ciudadana aumentó la desconfianza de los gobernadores respecto a la comunidad hebrea. Este resquemor se fue agudizando a partir de la década de 1650, cuando la Monarquía Hispánica empezó a desmoronarse en los frentes bélicos abiertos en Europa contra Francia y después, en el continente americano, contra Inglaterra. La presencia en el Mediterráneo occidental de la marina de guerra de Cronwell entre 1656 y 1658, en un intento frustrado, es verdad, por ocupar una posición estratégica en el Estrecho de Gibraltar desde la que ostigar el emporio comercial de Cádiz, alertó a los gobernadores militares de las ciudades costeras españolas y, muy especialmente, a los de los presididos norteafricanos, preocupados por las negociaciones que los agentes del Lord Protector llevaban a cabo con Fez.y Marruecos a fin de ocupar Ceuta, o con Argel, a quien prometen su ayuda para reconquistar Orán a cambio de obtener Mazalquivir ${ }^{53}$. Hacia 1668 esta situación de peligro aún no había desaparecido por completo para la plaza argelina, pues los ingleses ocupaban Tánger, cedida por el rey de Portugal a Carlos II Estuardo en concepto de dote por la boda con su hija, y su proximidad implicaba riesgos que no convenía fomentar manteniendo dentro de las murallas a un enemigo potencial, integrado por 476 personas, entre hombre, mujeres y niños, cuyos vínculos económicos con los árabes del entorno y con las juderías de Argel y Tremecen podían animarle a romper su fidelidad al monarca español, apoyando un ataque inglés o una acción conjunta anglo-argelina, de producirse tal alianza.

Para las autoridades militares de Orán y para el Consejo de Estado, la seguridad del presidio era vital por su destacada situación estratégica y su cercanía a las costas del Levante español, a un día de navegación de Cartagena ${ }^{54}$. Este elemento contribuyó de manera decisiva, imponiéndose sobre consideraciones religiosas, aunque éstas también tuvieron su importancia, en la resolución de expulsar a los judíos, a quienes se calificaba de arteros y traidores ${ }^{55}$. El miedo a motines sediciosos impulsó

52 Jiménez de Gregorio, F., op. cit., pág. 101; ISRael, J. I., op. cit., págs. 79-81.

53 SÁNCHEZ BELÉN, J. A., "La presencia inglesa en el Estrecho a fines del siglo XV||», I Congreso Internacional El Estrecho de Gibraltar, t. Ill. Ceuta 1988, pág. 32.

54 Braudel, F., El Mediterráneo y el mundo mediterráneo en la época de Felipe 11 , t. I. Madrid 1976, pág. 478 .

55 Conviene constatar que la literatura hebraica hace lo imposible por demostrar que los 
a los gobernadores a provocar disensiones en el seno de la comunidad hebrea con el propósito de dividirla, aprovechándose de la enemistad surgida entre los Cansinos y los Çaportas desde mediados de la década de 1630, cuando la Corona benefició a los primeros a instancias del Conde-Duque de Olivares, no obstante los servicios que hasta entonces había prestado Jacob Çaportas. La maniobra obtuvo su éxito más rotundo en 1657. No sabemos muy bien lo sucedido, aunque ciertos indicios apuntan a que algunas familias judías ordenaron a sus esclavos que no llevaran grano a la plaza. El marqués de los Vélez, de quien hemos tomado esta referencia, indica que no hubo pruebas bastantes para implicarlos ${ }^{56}$, pero aun así unos fueron sancionados con prisión y multa y otros con el destierro, entre ellos Jacob Çaportas, el xeque de la comunidad, cuyo cargo se transfirió a Abraham Cansino, quien lo ejercería junto a Samuel Çaportas, hermano del desterrado, una vez que se incorporase a la ciudad, pues por aquel entonces se hallaba en la península por negocios particulares. A partir de este momento la judería será gobernada por dos xeques, rechazándose la pretensión de Samuel Çaportas de ser el único con derecho pleno a desempeñar dicho cargo, así como los ruegos del anterior titular para reintegrarse en el ejercicio del empleo. Las razones alegadas en 1668 por don Fernando Joaquín Fajardo para mantener este biunvirato son dos: $\left.1 .^{a}\right)$ gobernarse mejor la judería y $2 .^{a}$ ) poder ejercer España un mayor dominio sobre ella, ya que estando dividido su gobierno entre Cansino y Çaportas «no es fácil el inclinarse más a una parcialidad que a otra" ${ }^{57}$. Con todo, estos últimos gozaban de un poder superior sobre sus rivales, pues si la familia Cansino tenía en sus manos el oficio de intérprete de la lengua árabe aquéllos poseían el cargo de capitán y en definitiva la capacidad de organizar militarmente a la comunidad. Es por ello que el marqués de los Vélez, recurriendo a un pretexto, despoje del empleo a Salomón Çaportas, hijo de Jacob Çaportas, nombrando en su lugar interinamente a Samuel Cansino, hasta entonces alférez, quien, al parecer, solicitó del Consejo de Guerra el nombramiento definitivo, privando así de toda influencia militar a la facción que más peligro podía ocasionar ${ }^{58}$.

de su nación jamás fueron infieles o traidores a los soberanos de los países donde residian, contradiciendo así la opinión castellana de que los avecindados en Amsterdam promovían la ruina de la Monarquía. Ver MECHOULAN, H., Hispanidad y judaísmo..., págs. $31-32$ y 46-47 asi como YeRUSHALMi, Yosef H., op. cit., págs. 236-238.

56. AHN, Estado, leg. 1.749. Carta del marqués de los Vélez, 23 de septiembre de 1668.

57 AGS, Guerra Antigua, leg. 2.189. Carta del marqués de los Vélez, 22 de ncviembre de 1668 .

58 Ibidem. Cartas de Salomón Çaportas, 12 de mayo de 1668 y 25 de julio de 1668. 
Estas medidas permitieron a los gobernadores fragmentar la unidad de los judíos haciéndolos más vulnerables y, presumiblemente, más conformes con las disposiciones que promulgasen, las cuales acatarian sin resistencia. No es aventurado atribuir, por tanto, el éxito de la expulsión a tales actuaciones, ya que les impidieron adoptar una postura firme en defensa de sus intereses. Aun asi, el marqués de los Vélez no escatimó el empleo de otros procedimientos coercitivos. En efecto, en el mes de septiembre de 1668 se prohíbe remitir cartas a España sin pasar por el registro de la secretaría del gobernador, aplicando sanciones a los infractores y a los capitanes de los bajeles que las transportasen. A esto se añade la orden de encarcelar a Samuel Çaportas en el castillo de Rosalcázar y a Salomón Çaportas en el de Santa Cruz con motivo de haber sido intervenida la correspondencia que venía a ellos dirigida en clave y cuyo contenido, aunque no se logró averiguar, supuestamente se juzgaba peligroso para la seguridad del presidio ${ }^{59}$. También jugó en contra de los judíos el sigilo con que fue planificada la expulsión, como se jacta de ello el marqués de los Vélez, pues a pesar de haber transcendido rumores de que algo se estaba fraguando en Madrid contra la judería se desconocía su alcance, lo que limitaba la capacidad de maniobra de los xeques, tanto o más que sus posiciones antagónicas:

«Nadie supo, señora, penetrar el secreto, y asi no tuvo lugar esta perversa nación de armarse de sus acostumbradas cautelas, con que se hallaron sin la esperanza de estorbar su salida, como también de que sus ruegos y súplicas no habían de ser oídos, y así, aunque algunos les consolaban, la respuesta de todos ellos era conocian no tenía remedion ${ }^{60}$.

Desde la óptica de la Corona, el destierro de los judíos de Orán era consecuente con los criterios adoptados en 1492 y en 1609 cuando se promulgaron las expulsiones de los hebreos españoles y de los moriscos: en todos los casos se primó la unidad religiosa y la seguridad política de la Monarquía a sabiendas de que se sacrificaba la economía del reino. Este sacrificio, no obstante, se consideró siempre un mal menor, en parte

s9 Sotomayor y VAlenzuela, L. J., Op. cit., fols. 10v-11v.

60 AGS, Estado de España, leg. 4.128. Informe del marqués de los Vélez, 5 de mayo de 1669. Del sigilo con que se llevaron a cabo los preparativos de la expulsión se hace eco también Sotomayor y Valenzuela, aunque su éxito lo relaciona con la providencia divina: "no se puede negar la asistencia que ha tenido del Espíritu Santo y con ella no es posible suponer el menor yerro en su prosecución. Se hace esto patente, más que por conjeturas, entre otras señales, en el inviolable secreto que se ha guardado, habiéndose fiado de tantos interlocutores más tiempo de dos años, sin que por ninguno dellos se haya deslizado la menor noticia" (op. cit., fol. 15). 
por el convencimiento de que los recursos propios serían capaces de conjugar las pérdidas derivadas de la diáspora en hombres y capitales. En el episodio que nos ocupa tal creencia estuvo fomentada por las autoridades militares de la plaza, que no dudaron un solo instante en representar el escaso beneficio que el Estado obtenía permitiendo vivir a los judíos a su sombra, pues la aportación que hacían a las finanzas reales por pechos y alcabalas se reducía a 17.000 maravedíes, cantidad en que se arrendaban tales impuestos - se ocultan a propósito los empréstitos otorgados en años precedentes-, muy inferior además a los sueldos que percibían algunas familias, cifrados en $\mathbf{4 0 . 8 0 0 ~ m a r a v e d i ́ e s , ~ y ~ a ~ l o ~ q u e ~ p e - ~}$ charían de residir en Tremecen o Argel ${ }^{64}$. De ser ciertos estos datos no cabe sino decir que apenas contribuían al mantenimiento de los gastos del presidio, cuyo importe se elevaba en 1668, según el contrato de asiento efectuado con Ventura Donis, a 105.720 escudos de vellón de a 10 reales, o sea, 35.944.800 maravedíes ${ }^{62}$. De cualquier modo, este aspecto no era relevante para el Consejo de Estado, ya que en ningún momento se pensó que la judería pudiera sufragar la presencia de los militares españoles y tampoco convenía que lo hiciera porque hubiera supuesto una dependencia peligrosa. Buena prueba de ello es que el arrendamiento de las contribuciones que estaba obligada la comunidad hebrea a pagar disminuyó progresivamente en el siglo xvi, evolucionando desde 3.150 .000 maravedíes anuales del período $1530-1534$ a 1.012 .500 maravedíes en 1539, suma que permaneció casi inalterada hasta el final de la centuria, en tanto que el presupuesto de la plaza osciló alrededor de los 11 millones de maravedies -entre 1530 y 1534 se enviaron de Madrid ocho millones, aparte el valor del arrendamiento, y en 1559 se consignaron 10.500 .000 maravedíes $-{ }^{63}$. Esta tendencia prosiguió en la centuria siguiente, entre otras causas porque la crisis económica general debió de afectar también a la región minorando las transacciones comerciales que los judíos mantenían con los árabes, aparte de que las rutas mercantiles que unían el interior de África con la costa se desviaron de Orán hacia

\footnotetext{
61 AHN, Estado, leg. 1.749. Carta del marqués de los Vélez, 23 de septiembre de 1668. Sobre este particular habia incidido en varios informes anteriores.

62 AGS, CJH, leg. 1.913. Relación de lo que ha de proveer Ventura Donis para los presidios en 1668. En este mismo legajo se encuentra el contrato firmado con Ventura Donis para la provisión de Orán en los años 1666 y 1667 . En este asiento la cantidad estipulada es de 60.000 escudos de vellón de a diez reales por el citado período, es decir, 30.000 escudos para cada año, que se entregarian al pagador de Cartagena para conducirlos a la plaza.

${ }_{63}$ ULLOA, Modesto, op. cit., págs. 540-541. Braudel, utilizando un informe financiero de 1564-1568, indica que la soldada de la guarnición ascendería a 33.660.000 maravedís (op. cit., t. II, pág. 275).
} 
Argel, fenómeno ya observado, cuando menos, desde mediados del siglo XVI, como así lo señala Braudel ${ }^{64}$.

Con todo, la participación financiera de los hebreos oraneses no se ciñó exclusivamente al pago de tributos personales y alcabalas, pues hay indicios que apuntan a la concesión de préstamos, tal que, por ejemplo, el otorgado al parecer en 1656 a través de Jacob Cansino, evaluado en 800.000 ducados, cifra fabulosa en verdad y difícil de recuperar a corto 0 medio plazo ante la penuria del Estado ${ }^{65}$, lo cual repercutiría desfavorablemente en la comunidad, endeudándose con los españoles. Esta hipótesis resulta verosímil no ya porque aluden a ella Samuel Çaportas y Abrahan Cansino en el memorial enviado al Inquisidor General en 1668, sino por otras manifestaciones muy significativas. Si en torno a 1636 los judíos adquirían casas de los cristianos para ampliar sus barrios, en los que vivían hacinados - asi lo refiere el vicario de Orán-, en 1667, sin embargo, el marqués de los Vélez describe una situación contraria: no sólo carecen de bienes raíces, sino que sus viviendas están cargadas de censos, es decir, hipotecadas, a favor de los cristianos, sus acreedores ${ }^{66}$. Por si cupiera alguna duda, el representante de Gran Bretaña en Florencia abunda al respecto cuando expone en su correspondencia que el duque de Saboya autorizó la residencia en Villafranca de Niza nada más que a las familias pudientes expulsadas de Orán, viéndose obligadas las restantes - unas 300 personas - a trasladarse a Liorna ${ }^{67}$. Entre los afortunados se encontrarían los Çaportas y tal vez los Cansinos, pues nos resistimos a creer que estos últimos estuvieran en la miseria que el gobernador describe cuando apoyaba su nombramiento como intérprete de la lengua árabe. Es posible, no obstante, que los Çaportas no tuviesen ya la fortuna que se atribuía a Jaho Çaportas ${ }^{68}$, pero cabe suponer que no fuera muy inferior. De hecho, el destacado mercader Felipe de Moscoso, establecido en Alicante en torno a 1660, era hijo de Jacob Çaportas y a finales de la década negociaba en Orán con su tío Samuel Çaportas y con varias firmas de conversos portugueses afincadas en Liorna, realizando diversos viajes de negocios al presidio y a Génova antes de fallecer en el año $1680^{69}$.

64 Braudel, F., op. cit., t. II, pág. 278.

65 Barrionuevo, J. de, Avisos, t. I, pág. 272, carta 141; Caro Baroja, J., La sociedad criptojudía..., pág. 63. Sobre el estado de la hacienda en este período, Domínguez OrTiz, A., Política y hacienda de Felipe IV. Madrid 1960; IsaAeL, J. I., op. cit., pág. 76.

66 AHN, Estado, leg. 1.749. Carta del marqués de los Vélez, 8 de junio de 1667; JIMÉNEZ DE Gregorio, F., op. cit., pág. 99.

${ }_{67}$ Istael, J. I., European Jewry in the Age of Mercantilism, 1550-1750. Oxford 1985, paig. 157.

68 Jiménez de Gregorio, F., op. cit., pág. 98.

69 Kamen, H., La España de Carlos II. Barceiona 1980, págs. 219-226. 
Tuviesen o no dificultades financieras los judíos oraneses, el informe del marqués de los Vélez es obvio que perseguía un objetivo importante: desacreditarles también en este terreno. Con ello, aparte de reforzar sus anteriores argumentos (unidad religiosa y seguridad política), conseguía encubrir una realidad que causaba enorme malestar entre los españoles de la plaza pero que no podia ser aireada: desde la conquista de Orán por el cardenal Cisneros dominaban el comercio de granos y, como sucedía en Tetuán y Fez, seguramente también en Tremecen y Argel, eran intermediarios en el tráfico de esclavos y en la redención de cautivos cristianos ${ }^{70}$. Tales actividades eran deseadas por los españoles, sobre todo el monopolio de la venta de trigo, ya que las copiosas cosechas de la zona, a pesar de los métodos de cultivo atrasados que practicaban los árabes ${ }^{71}$, eran una fuente de riqueza estimada por los beneficios que generaba su exportación, dada la diferencia que existía entre el precio pagado a los productores y el obtenido en los mercados de Italia, España y plazas norteafricanas de Ceuta y Melilla, dependientes del cereal ibérico $y$, cuando éste escaseaba, como ocurrió a finales de los años 1650 y 1660 , del producido en Orán ${ }^{72}$. Para hacernos una idea de la abundancia cerealística de la región -algunos autores liegan a decir que el presidio se convirtió en el puerto de salida del trigo africano ${ }^{73}$-, se puede recordar el asiento suscrito en 1597 por Juan Pascual y la Corona para adquirir 70.000 fanegas de trigo oranes con destino a las galeras y fronteras de España, recibiendo a cambio licencia para extraer otras 30.000 fanegas de cebada que beneficiaría por su cuenta. Respecto de las ganancias generadas por este comercio basta mencionar que el Consejo de $\mathrm{Ha}$ cienda, cuando otorgó a Juan Pascual la licencia antes aludida, consideró que le representaria "buena parte de beneficio propio" ${ }^{74}$ y no exageraba,

70 Sobre este particular ver el artículo presentado en este número por Guillermo Gozalbes Bustos. En Melilla, por ejemplo, que no cuenta con judería, el aprovisionamiento lo realizan mercaderes hebreos que actúan de intermediarios entre los españoles y los árabes y aun de espías. Ver Salafranca Ortega, J. F., La presencia hebrea en Melilla hasta 1874. Melilla 1987, págs. 10-11; AHN, Estado, leg. 1.749. Carta de Abrahan Cansino y Jacob Çaportas, 20 de mayo de 1668; IsRael, J. I., op. cit., pág. 76.

71 Para estos pormenores, JimÉnez de Gregorio, F., op. cit., pág. 103.

72 Archivo de la Real Academia de la Historia (ARAH), Col. Salazar y Castro, K-16, 9/641, fols. 108-132. Compras de trigo de Orán para Ceuta en 1635-1636; LUXAN MELÉNDEZ, Santiago de, “Contribución al estudio de los presidios españoles del Norte de África. Las dificultades de la plaza de Ceuta para abastecerse de trigo (1640-1668)", Hispania, XXXV, 130. Madrid 1975, págs. 321-342.

73 Braudel, F., op. cit., t. I, pág. 761.

74 Thompson, I. I. A., op. cit., pág. 318 . En las décadas de 1620 y 1630 los asentistas encargados de proporcionar trigo a Orán gozaron del monopolio de exportar granos de esta región a España, vendiendo las licencias de saca cuando las cosechas eran buenas en África a diez y doce reales la fanega. 
pues, según testimonio del capitán Diego Suárez, el valor del trigo de Orán a mediados del siglo XVI era cuatro o cinco veces inferior al que tenía en España, diferencia que con el transcurso del tiempo debió de aumentar, en particular en épocas de malas cosechas por lluvias o sequías ${ }^{75}$. Así, por tanto, la salida de los judíos oraneses mejoraría la economía de los españoles del presidio al reemplazarles, aparte de que sus patrimonios se verían incrementados con los vendidos apresuradamente por los expulsados, pero esto en nada beneficiaba a la Corona que perdía, de pronto, unos magníficos agentes y unos prestamistas avezados, motivo por el cual pensamos que quienes propiciaron el fin de la judería dentro del presidio buscaban el logro de sus intereses personales y no los del Estado, hábilmente camuflados bajo el velo de la unidad religiosa y de la seguridad militar, dos objetivos que no podían dejar indiferentes a la reina, al valido y al Consejo de Estado.

\section{ORGANIZACIÓN}

A partir del 31 de octubre de 1668, fecha en la que doña Mariana de Austria notifica al marqués de los Vélez su decisión de expulsar a los judíos, éste, provisto de amplias atribuciones, comienza a organizar el viaje con todo secreto, sin que trascienda a la judería ni al Consejo de Guerra, como así se le había ordenado que lo hiciese, procurando tenerlo todo dispuesto en un breve plazo de tiempo, aunque se le deja a su arbitrio elegir el momento más oportuno para ejecutarlo ${ }^{76}$. La empresa, desde luego, era ardua: había que fletar los buques que los transportaran, disponer de las vituallas necesarias durante la travesía, reparar las murallas de la ciudad dotándolas de cañones y solicitar del Consejo de Guerra armas, municiones, dinero y tropas para asegurar la plaza y evitar posibles altercados protagonizados por los judíos al enterarse de su expulsión o repeler algún ataque árabe en el caso de estar informados por sus espías de la salida de los hebreos, pues sería una ocasión excelente para desencadenarlo ante el posible o seguro apoyo de la judería.

Desde el mes de mayo de 1668 el gobernador de Orán, tal vez convencido de que la expulsión estaba ya decantada - hemos de recordar que su madre era el aya de Carlos ll y gozaba de la estima de la reina y del valido ${ }^{77}$-, venía alertando a Madrid sobre el pésimo estado en que

75 Braudel, F., op. cit., t. I, pág. 761.

76 AHN, Estado, leg. 1.749. Despacho de la reina al marqués de los Vélez, 31 de octubre de 1668 .

7 Maura, Duque de, Vida y reinado de Carlos II, t. I. Madrid págs. 104 y 124. 
se hallaba la defensa del presidio, sin hombres, sin armas $y$, lo que es más grave, con las fortificaciones muy dañadas, pues aunque habia emprendido reparaciones en los castillos de Santa Cruz, San Gregorio y fortaleza de Mazalquivir, quedaba todavía sin arreglar el castillo de Rosalcázar y un lienzo de la muralla que se había derrumbado en ese mismo mes. Para remediar esta situación solicita se le envíe gente de la milicia del reino de Murcia con sus armas y los 30.000 escudos que están consignados al presidio, así como que se prohíba extraer trigo de la zona, pues con el dinero que produce su venta podrá acometer los arreglos que precisan realizarse, toda vez que sospecha de un ataque de los argelinos por los preparativos que llevan a cabo, según se desprende de los informes obtenidos de un renegado quien, por cierto, apunta que tales maniobras no van dirigidas contra la plaza, sino para excusar asistir a los turcos con catorce bajeles en un proyectado e inminente conflicto armado con Venecia ${ }^{78}$.

Las peticiones formuladas por el marqués de los Vélez son aprobadas por el Consejo de Guerra salvo en el punto relativo a la gente de guerra, conformándose con ordenar estuviese prevenida la milicia del reino de Murcia ante cualquier eventualidad ${ }^{79}$. El 23 de julio de 1668, sin embargo, el gobernador escribe dando cuenta a la reina de la llegada del dinero y de doscientos hombres procedentes de las levas efectuadas en el reino de Granada, así como de la fineza del marqués del Viso, quien, viendo la poquedad de armas que había en el presidio, ordenó entregar al mayordomo de la artillería cien arcabuces de la dotación de las galeras, ya que el armamento requerido en su día aún no se había despachado ${ }^{80}$. En el mes de septiembre, y a consulta del Consejo de Guerra, una vez comprobadas las existencias del arsenal de Orán y lo que se necesitaba, según relaciones efectuadas por el veedor y contador, se resuelve proveer al marqués de los Vélez con doscientos carabinas, trescientos arcabuces, trescientas astas de picas para lanzas de caballería y manejo de la artilleria, cien cajas de abrazaderas y llaves para otros tantos cañones de mosquete, doscientos pares de frascos para arcabuces y trescientos más para mosquetes con horquilla, aparte de quinientos quintales de pólvora de la labrada en Murcia, ciento cincuenta quintales de pólvora inútil que

78 AGS, Guerra Antigua, leg. 2.164. Cartas del marqués de los Vélez, 16 de mayo de 1668.

79 Ibidem. Consulta del Consejo de Guerra, 13 de junio de 1668. No obstante, se despachan órdenes a Lorca, Murcia y demás lugares de la región para que prevengan la milicia, lo cual es acatado rápidamente (lbidem, leg. 2.189. Cartas de Lorca y de Murcia, 16 de julio y 3 de julio de 1668).

80 AGS, Guerra Antigua, leg. 2.164. Cartas del marqués de los Vélez, 23 de julio y 2 de agosto de 1668 . 
hay en Cartagena después de ser refinada, 100 quintales de hierro, bergajón y platina para aderezo de los ajustes de la artillería, seis quintales de hierro en trozos para hacer almadenes y cuñas e instalarlos en las fortificaciones $y$ dos quintales de acero fino ${ }^{81}$. El 28 de octubre todavía no se había expedido este material, como informa a la reina y al Consejo de Guerra. Mientras, sigue reparando las murallas, aunque precisa de cal, motivo por el cual solicita se ajuste en Madrid un asiento de seis mil u ocho mil cahíces que podrán embarcarse en los buques que han de cargar trigo de Orán, facilitándose este intercambio con reducir los derechos reales en una cierta cantidad. Asimismo, considera imprescindible construir una torre desde la que proteger una fuente, vital para el suministro de agua, necesitando a tal efecto algunos maestros que don Carlos $\mathrm{Ca}$ lonne, gobernador militar de Cartagena, y el corregidor de Murcia podrán contratar en sus respectivas demarcaciones, junto con algunos artilleros y "encabalgadores" de los cañones que deben instalarse en las murallas y en la citada torre, de los que tampoco anda sobrado, pues requiere se le envíen doce piezas de Cartagena ${ }^{82}$. A finales del mes de diciembre la mano de obra está lista para ser embarcada en cuanto lo disponga el gobernador de Orán ${ }^{83}$. No ocurre lo mismo con el material bélico, pese a las órdenes dadas por la reina y el Consejo de Guerra para que se remitan desde la fábrica de Plasencia a Cádiz y desde aquí al presidio, haciendo escala las naos en Cartagena para subir a bordo la pólvora, ya que el 21 de enero de 1669 el Consejo de Guerra recomienda a doña Mariana que expida nuevos despachos sobre este particular. No obstante, hasta el 9 de marzo no se ejecutaron las órdenes, arribando a Orán los buques hacia el 20 o el 21 de dicho mes, después de que un temporal obligara a unas naves a refugiarse en Alicante y a otras a regresar a Cartagena, de donde habian partido ${ }^{84}$.

Br lbidem, leg. 2.189. Memoria de las armas, municiones y otros géneros que la reina nuestra señora ha resuelto, en consulta de 5 de septiembre de 1668, se provea para las plazas de Orán. Las relaciones de lo que el marqués de los Vélez necesitaba aparecen en este legajo y están fechadas en 8 de junio de 1668. La consulta del Consejo de Guerra aprobando el envío del material en el leg. 2.165 de esta misma sección.

82 Ibidem, leg. 2.166. Carta del marqués de Vélez, 28 de octubre de 1668 y consulta del Consejo de Guerra, 7 de diciembre de 1668.

в3 Ibidem. Carta de don Carlos Calonne, 24 de diciembre de 1668 y del corregidor de Murcia, marqués de Sotraga, 25 de diciembre de 1668.

${ }_{84}$ Ibidem, leg. 2.193. Consulta del Consejo de Guerra, 2 de enero de 1669, Consulta del mismo en 21 de enero de 1669 y en 11 de febrero de 1669; leg. 3.505. Carta del marqués del Viso, 13 de marzo de 1669 y Consulta del Consejo de Guerra, 22 de marzo de 1669; AGS, Estado, leg. 2.688. Carta del marqués del Viso, 25 de marzo de 1669 y carta de don Carlos Calonne, 25 de marzo de 1669. 
También resultó difícil la recluta de las tropas que necesitaba don Joaquín Fajardo de Requesens y Zúñiga para proceder a la expulsión de los hebreos y que estaba prevista en la consulta del Consejo de Estado del 13 de octubre de 1668. El obstáculo mayor lo opuso el Consejo de Guerra que desconocía las intenciones de la reina. El pretexto ideado por el gobernador de Orán para que se le asistiese con gente de guerra, y que fue aprobado por el Consejo de Estado, consistía en un previsible ataque de los argelinos ${ }^{85}$. La artimaña, bien pensada, fuerza es reconocerlo, estuvo a punto de fracasar. En el mes de julio habían llegado al presidio doscientos soldados, número suficiente para mantenerlo bien defendido en el caso de un ataque aislado de los árabes del contorno. En los meses siguientes, el marqués de los Vélez insiste, sobre todo a partir de octubre, en que se envíen algunos hombres de las levas, de la milicia de Murcia o del tercio que se va a alojar en Cartagena porque todos los informes recibidos apuntan a una serie de preparativos militares de los moros que bien pudieran ir dirigidos contra la plaza ${ }^{86}$. Simultáneamente, y para evitar dilaciones, escribe al gobernador de Cartagena y a la ciudad rogando que organicen con premura una tropa de trescientos soldados, asegurando que su permanencia en el presidio será breve ${ }^{87}$. Don Carlos Calonne despacha de inmediato emisarios a Lorca y Murcia con el beneplácito del Consejo de Estado, pues el tercio de Toledo que estaba previsto arribase a Cartagena había sido disuelto por orden del Consejo de Guerra ${ }^{88}$. El 9 de febrero de 1669, tal como registran las actas capitulares de Cartagena, estaban en la ciudad las milicas de Murcia, Lorca, Totana y Alhama, pero faltaban por formarse las compañías de Cartagena debido a que el concejo, sin recursos financieros, se había visto precisado a poner en arriendo

85 AHN, Estado, leg. 1.749. Carta del marqués de los Vélez, 13 de junio de 1668. Que el plan se ejecutó como lo propuso el gobernador de Orán se desprende de la siguiente carta del mismo al Consejo de Estado fechada el 20 de enero de 1669: "en 10 del corriente represente a la reina nra sra por la parte de la secretaria de Guerra las noticias con que me hallaba de las mahalas de turcos que me decian pasaban de Argel a Tremecen, y dije en esta ocasión lo que importaba tener estas plazas en defensa para cualquier frangente (sic) que pudiera suceder, "valiéndome de este motivo para pretextar el socorro que pedia del reino de Murcia o del tercio de Toledo [...] y acudir con la gente de cualquier de estas dos partes a la expulsión de los hebreos'" (ibidem).

${ }^{86}$ AGS, Guerra Antigua, leg. 2.193. Cartas del marqués de los Vélez, 26 de noviembre de 1668, 3 de enero de 1669, 10 de enero de 1669 y 21 de enero den 1669.

87 Archivo Municipal de Cartagena (AMC), Actas Capitulares (AA.CC.), Libro 27, fols. 684 y ss. Carta del marqués de los Vélez a la ciudad de Cartagena, 9 de enero de 1669

so AHN, Estado, leg. 1.749. Carta de don Carlos Calonne al Consejo de Estado, 12 de enero de 1669 y Consulta del Consejo de Estado, 24 de enero de 1669. La noticia de la disolución del tercio de Toledo en AGS, Guerra Antigua, leg. 2.193. Consulta del Consejo de Guerra, 6 de febrero de 1669 a una orden de la reina de 31 de enero de 1669 solicitando se acelerara el traslado de dicho tercio a Cartagena. 
la renta de algunos bienes propios, comisionando a dos regidores para formalizar el contrato con el arrendatario, si lo había ${ }^{89}$. Estas disposiciones, empero, fueron inútiles por ignorar el Consejo de Guerra el intento que perseguían. Según este organismo, las cartas del marqués de los Vélez, que respondían al plan trazado con la reina y el Consejo de Estado, eran infundadamente alarmistas y por ello desestima el embarque de las compañías formadas, ordenando se disuelvan, como así lo ejecuta don Carlos Calonne ${ }^{90}$. El asombro e indignación del marqués de los Vélez ante este suceso es indescriptible. En la carta que escribe al gobernador de Cartagena le reprocha con dureza haber antepuesto las órdenes del Consejo de Guerra a las que había recibido de la reina a través del despacho de 31 de octubre de 1668, no valiéndole excusa alguna, pues obrando de esa manera se aventuraba la empresa que tenía encomendada:

«si para los principios de la luna que viene no está aquí la gente de guerra queda frustrada la Real Voluntad de S.M., el servicio que yo esperaba hacer y la satisfacción que a todo este reino se diera de que no había sido sin causa llamada la gente, que aunque los recelos que tenemos de Argel y de mahalas podían ocasionar la prevención, nunca la hubiera yo anticipado tanto si no fuera por la execución de otro servicio, que ni se puede saber ni dar a entender hasta el día de su efecto por constituir su logro en el secreto, el cual se aseguraba con el pretexto de los avisos de enemigos. Doy cuenta a S.M. de todo por la vía a quien toca y a V.S., como amigo, le pido distinga la orden del Consejo de Estado de la del de Guerra y execute la primera, pues no le puede estar bien otra cosa. Y como gobernador y capitán general de estas plazas (porque no me pare perjuicio en ningún tiempo ni se atribuya a omisión mía el dejar de hacerse el servicio) le protesto la dicha orden y le requiero de parte de S.M. serán todos los daños y costes por cuenta de V.S., a quien suplico perdone el hablar en esta forma, que como estoy obligado en mirar primero por mi crédito que atender otra cosa no es preciso usar de estilo para que le resguarde" ${ }^{\text {?' }}$.

La reprimenda dio sus frutos, pues don Carlos Calonne despachó con urgencia propios a Murcia, Lorca, Totana y Alhama para que enviasen gente con destino al socorro de Orán ${ }^{92}$. El 2 de marzo las milicias del

s9 AMC, AA.CC., Libro 27. Sesión del 9 de febrero de 1669.

9o AGS, Guerra Antigua, leg. 2.193. Consulta del Consejo de Guerra, 2 de enero de 1669 y 11 de febrero de 1669; Sotomayor y VALENZUELA, L. C., op. cit., fol. 13.

${ }_{91}$ Ibidem. Carta del marqués de los Vélez a don Carlos Calonne, 22 de febrero de 1669 y Carta del mismo al Consejo de Estado, 22 de febrero de 1669; Consulta del Consejo de Estado, 9 de marzo de 1669. De la indignación del marqués de los Vélez se hace eco Sotomayor $y$ VALENZUELA, L. J., op. cit., fol. 13.

${ }_{92}$ Ibidem. Carta de don Carlos Calonne al Consejo de Estado, 27 de febrero de 1669 y Consulta del Consejo de Estado, 27 de febrero de 1669. 
reino de Murcia están preparadas para ser transportadas, si bien sólo se lograron reclutar doscientos cuarenta y nueve hombres con sus municiones, ya que los lugares de Cartagena se negaron a colaborar y prevenir sus compañías ${ }^{93}$.

El tercer escollo que el marqués de los Vélez tuvo que afrontar fue el pasaje de la tropa reclutada. La Corona había dispuesto que el viaje se realizara en las galeras de España al mando del marqués del Viso, pero el gobernador de Orán sabía de cierto que no estarían en el puerto de Cartagena cuando las quisiese utilizar. Anticipándose a esta eventualidad concierta con los patrones de tres saetías atracadas en Mazalquivir que se dirijan a Cartagena donde se embarcaría la milicia, las armas y las municiones que precisaba ${ }^{94}$. Esta disposición, aprobada por el Consejo de Estado, que ordena a don Carlos Calonne que si las galeras de España no están a punto en el instante de recibir el despacho del marqués de los Vélez solicitando la gente de guerra la transporte en otras naos, no pudo ejecutarse porque el Consejo de Guerra, ignorando este despacho, prohibió al gobernador de Cartagena que embarcase las milicias en las tres saetias, justificándose ante la reina con el argumento, fundado, desde luego, de que tales naves no podrían oponer resistencia a un ataque corsario $^{95}$. El disgusto del marqués de los Vélez fue tan grande como el sufrido cuando se disolvieron las compañias del reino de Murcia: sus planes se demoraban peligrosamente, dado que el marqués del Viso, a quien se había despachado una orden comunicándole que partiese cuanto antes hacia Cartagena, no inicia su viaje hasta el 16 de febrero de $1669^{96}$. No obstante, el Consejo de Estado, después de reflexionar sobre el asun-

93 AGS, Estado, leg. 2.688. Real Decreto de 30 de marzo de 1669 y Consulta del Consejo de Estado, 19 de marzo de 1669. Sobre la resistencia de los lugares de Cartagena a participar en la milicia, no obstante ser una de sus obligaciones, hay varias referencias en las sesiones del cabildo de la ciudad, como la queja formulada, años después, en 1683, con motivo de un contencioso entre el ayuntamiento y los vecinos del campo cartagenero por asuntos fiscales. Ver al respecto Sánchez Belén, J. A. y Alcaraz Hernández, A. T., "Oligarquía municipal e impuestos: La asonada del campo de Cartagena en 1683", Espacio, Tiempo y Forma, Madrid, serie IV, $n .{ }^{\circ} 4,1992$, págs. 163-202. Según el marqués de los Vélez, tanto como agradecer a las ciudades de Murcia, Lorca, Totana y Alhama por la formación de las compañías, hay que premiar a varios capitanes "que con todo gusto se dedicaron a fomentar se levantase la gente", gastando de su dinero para proveer el mantenimiento de los soldados desde sus lugares de recluta a Cartagena, dada la cortedad de recursos económicos de las ciudades y villas (AGS, Estado, leg. 4.128. informe del marqués de los Vélez, 5 de mayo de 1669).

94 AHN, Estado, leg. 1.749. Carta del marqués de los Vélez, 20 de enero de 1669; AGS, Guerra Antigua, leg. 2.193. Carta del marqués de los Vélez, 21 de enero de 1669; SotomaYor Y VALENZUELA, L. J., Op. cit., fol. 12.

95 Ibidem. Consulta del Consejo de Estado, 24 de enero de 1669; AGS, Guerra Antigua, leg. 2.193. Consulta del Consejo de Guerra, 11 de febrero de 1669.

${ }_{96} \mathrm{Ibidem}$. Carta del marqués del Viso, 16 de febrero de 1669. 
to, tampoco se muestra partidario de arriesgar el traslado de los soldados embarcándoles en las saetías fletadas ("será mal caso que en lugar de echar los judíos se perdiesen cuatrocientos cristianos"), razón por la cual propuso escribir al gobernador de Orán para que retrasara la salida de los hebreos hasta que llegasen las galeras, pues con su presencia se aseguraba el éxito de la empresa ${ }^{97}$.

El arribo a Cartagena de la flota del marqués del Viso a finales de febrero no implicó, empero, su pronta partida hacia Orán, ya que la milicia, como hemos visto, había sido disuelta por el general Calonne y era preciso reagruparla de nuevo. Todo estaba dispuesto para zarpar el 3 de marzo, pero en esa fecha el marqués del Viso recibe órdenes, que se supone invalidaban las precedentes, con el encargo de enviar tres galeras a Barcelona para conducir al duque de Osuna, virrey de Cataluña, a su nuevo destino de Milán. Cartas del marqués de los Vélez y de don Carlos Calonne informan al Consejo de Guerra de que dicho pasaje se debe posponer ante la prioridad de socorrer la plaza de Orán. Aunque este organismo reacciona con rapidez, escribiendo al marqués del Viso en 8 de marzo para que se abstenga de desplazar las tres galeras a Barcelona, ya era demasiado tarde ${ }^{98}$. Semejante descoordinación, que el Consejo de Guerra trata de justificar argumentando no haber «tenido noticia alguna de los motivos que obligaban a mandar pasase la dicha gente al socorro de Orán", provoca que se demore por unos dias el transporte de la milicia, a lo que contribuyó también la deserción de algunos marinos y soldados de infantería de marina, reduciéndose las dotaciones, y el mal estado de una galera, incapacitada para navegar, de suerte que fue preciso sustituirla por un navio genovés de cuarenta cañones fletado a tal efecto, en tanto que las saetias contratadas por el marqués de los Vélez se destinaron a transportar las armas y municiones ${ }^{99}$. El 9 de marzo se inicia la travesía sin el auxilio de las galeras, pero «un temporal y viento contrario» cuando estaban las naves a catorce leguas las desvía de su ruta, regresando dos saetías al puerto y refugiándose las otras dos y el buque que

97 Ibidem. Consulta del Consejo de Estado, 27 de febrero de 1669.

98 Ibidem. Carta de don Carlos Calonne, 27 de febrero de 1669; AGS, Guerra Antigua, leg. 3.505. Consulta del Consejo de Guerra, 9 de marzo de 1669.

99 AGS, Guerra Antigua, leg. 3.505. “Relación de la gente de Infantería y mar que de las cinco galeras de España abajo nombradas se han huido de ellas desde el veinte y seis de febrero pasado de este año que entraron en el puerto de esta ciudad de Cartagena hasta primero del corriente mes que se les toma la muestran; AGS, Estado, leg. 2.688. Consulta del Consejo de Estado, 7 de abril de 1669; AGS, Guerra Antigua, leg. 3.518. Real Decreto de 9 de marzo de 1669 y carta del marqués del Viso, 25 de marzo de 1669; Sotomayor y VALENZUELA, L. J., op. cit., fol. $13 \mathrm{v}$. 
conducia la tropa bajo la Torre de Estacio, a seis leguas de Cartagena -en un principio se dijo que habían llegado a Alicante-. Dos días después, con viento favorable, parten de nuevo, mas las saetías que habian salido de Cartagena vuelven al avistar tres navios y sospechar que fueran corsarios. El 25 de marzo todavian estaban amarradas en el puerto, ahora por el mal tiempo, aunque las otras naos lograron arribar felizmente a Orán el 22 de marzo. Cinco días más tarde atracan por fin las saetías que no habían podido zarpar de Cartagena por el temporal ${ }^{100}$.

\section{LA SALIDA DE LOS JUDIOOS}

Tan pronto como el marqués de los Vélez recibe los refuerzos militares promulga un bando en la plaza mayor de la ciudad, rodeada por la infantería del presidio ${ }^{101}$, donde, tras insertar el decreto de expulsión firmado por doña Mariana de Austria en 31 de octubre de 1668, establece una serie de disposiciones que deben ser observadas por los españoles y los judíos a fin de acelerar la salida de éstos. Varios aspectos impor-

100 AGS, Estado, leg. 2.688. Carta de don Carios Calonne, 25 de marzo de 1669 y consulta del Consejo de Estado. 7 de abril de 1669; AGS, Guerra Antigua, leg. 3.505. Consulta del Consejo de Guerra, 22 de marzo de 1669 sobre Carta del marqués del Viso, 13 de marzo de 1669; SOTOMAYOR Y VALENZUELA, L. J., op. cit., fols. $13 v$ y $15 \mathrm{v}$. Este mismo autor da una breve relación de los capitanes y los soldados que reclutaron y llevaron a Orán: comandante don Juan de Alva con una compañía del tercio de Toledo (60 hombres); capitán don Payo Félix Afán de Rivera, con 75 soldados; capitán don Alonso de la Jara y Molina, regidor perpetuo de Cartagena, con 65 soldados; don Alfonso González de Sepúlveda, hijo del anterior, visitador general de las torres de la costa murciana, con 40 hombres; el capitán don Bartolomé Valerio Alarcón, alcalde de Alhama, con una treintena de soldados (op. cit., fol. 14v).

${ }_{101}$ En los siguientes términos describe Sotomayor y Valenzuela el ambiente en que se promulgó el edicto de expulsión de la judería de Orán: "(el marqués de los Vélez) mandó que se ocupase la Plaça principal de esta ciudad con toda la infantería della en forma de escuadrón, que al punto se executó el militar estruendo de trompetas, pífanos y caxas, hermoseado con la variedad de diez y seis banderas y dos estandartes, que con orden y bizarra disposición, guarnecidos los costados con 300 caballos, los capitanes con ostentación de galas, aunque ignorando la novedad de aquel repentino movimiento. Amaneció este mismo día el frontispicio de las casas del Ayuntamiento adornado de ricos paños, sitial y dosel para la persona del capitán general, vista que dexo a los ánimos perplejos, los discursos varios, las imaginaciones ofuscadas y últimamente las preguntas y respuestas sin proporción ni concierto. En esta confusa admiración estaban apoderados los juicios, cuando entró en la Plaça el Excelentisimo Señor Marqués de los Vélez asistido y acompañado de su guarda española, a quien como su capitán general la abatieron los cruzados tafetanes, como es costumbre, en señal y reconocimiento de obediencia, continuándose el marcial alboroto hasta que con autoridad magestuosa tomó la silla que le tenían destinada y a la primera señal de atención quedó la referida Plaça en tan profundo silencio como si les faltara a todos los presentes la vital respiración. Y puesto el escribano mayor del cabildo en parte que pudiera ser oído de la gente que con notables deseos esperaba salir de tantas dudas, dixo (aquí reproduce el bando)" (op. cit., fols. 15v-16). 
tantes contempla dicho bando: $10^{\circ}$ seguridad física de los expulsados; $2 .^{\circ}$ precio justo en la venta de sus propiedades; $3 .^{\circ}$ breve espacio de tiempo para disponer el pasaje; $4 .^{\circ}$ nombramiento de comisarios para liquidar en dos meses los bienes que en el momento de la partida no hubiesen sido enajenados o cobrar las deudas a que eran acreedores; $5 .^{\circ}$ elección por los expulsados del lugar al que deseaban trasladarse ${ }^{102}$.

Todos los ministros implicados en la gestión del destierro habían coindido en que no se debía causar agravios ni vejaciones a los hebreos, como así se decreta, "por ser muy conforme a la ley natural y a la obligación cristiana", en palabras del cardenal Aragón ${ }^{103}$. Asumiendo este criterio, el marqués de los Vélez ordena al licenciado don Franciso de Buendía, alcalde mayor de la ciudad y auditor de la gente de guerra, que no permita a nadie apropiarse de ningún bien de los desterrados ni adquirirlo a un precio inferior al estipulado, procediendo sumariamente en cuantas demandas fuesen presentadas por los perjudicados. Asimismo advierte a los vecinos que serán sancionados con penas diversas si se atreven a maltratar, de obra o de palabra, "a estos desdichados, ciegos en su error y abatidos por su culpa", oscilando las penas, en función del estado y calidad de los culpables, desde la pérdida de los oficios públicos, si los tuvieran, hasta el destierro a Melilla por diez años, si es gente principal, y si no lo es a servir en las galeras por igual tiempo. Finalmente, manda a los oficiales de guerra que observen estas normas y las hagan cumplir a los soldados, pues ael que se hallare presente a cualquier vejación o mal tratamiento que se hiciere y no prendiere o hiciese prender al que lo ejecutare, será suspenso de su puesto, y si estuviere de ronda, por lo más que le incumbe la obligación, privado de él» ${ }^{104}$.

Motivo de honda preocupación para la Corona fue también fijar el plazo en que debían partir los judíos una vez promulgado el decreto. El marqués de los Vélez en su consulta del 13 de junio de 1668 había sugerido dos meses, tiempo prudencial, a su juicio, para que pudieran liquidar sus haciendas y disponer el pasaje con comodidad; por si acaso quedaban algunos negocios pendientes, aconsejaba se permitiese la estancia de dos o tres individuos nombrados por la comunidad hasta concluirlos, no prolongando sus gestiones más allá de dos meses ${ }^{105}$. La propuesta, que rebate juicios adversos contra su persona ${ }^{106}$, no fue aprobada por el Con-

102 AGS, Estado, leg. 4.128. Bando que en 31 de marzo de 1669 se publicó en Orán sobre la expulsión de los hebreos. Lo reproduce también SOTOMAYOA Y VALENZUELA, L. J., op. cit., fols. 16-18v.

${ }_{103}$ AHN, Estado, leg. 1.749. Voto particular del cardenal Aragón, 5 de octubre de 1667.

104 AGS, Estado, leg. 4.128. Bando que en 31 de marzo...

105 AHN, Estado, leg. 1.749. Carta del marqués de los Vélez, 13 de junio de 1668.

106 AMADOR DE los Ríos, J., op. cit., pág. 828. 
sejo de Estado, cuyos miembros emitieron pareceres opuestos entre sí: el cardenal Aragón suscribió la sugerencia del marqués de los Vélez; el duque de San Lucar fue partidario de concederles seis días y a los apoderados que designasen dos meses; el padre Nithard se conformó con el dictamen de la Junta, tal como lo formuló en su consulta del 12 de julio de 1668, es decir, expulsión inmediata y permanencia en el presidio de tres o cuatro personas delegadas para beneficiar las haciendas de los desterrados ${ }^{107}$. El 13 de octubre de 1668 el Consejo se abstiene de establecer un plazo mínimo para que salgan, si bien resuelve que se haga "con la brevedad mayor que se pueda", asumiendo en lo restante la propuesta del gobernador de Orán. Por este motivo, el marqués de los Vélez, en el bando del 31 de marzo de 1669, ordena, en contra de su opinión, "que todos los judíos que habitan en esta ciudad, con sus familias, hijos y mujeres, dentro de ocho días primeros siguientes de esta publicación, que se cumplirán el lunes 8 del mes que viene, salgan della a hacer viaje» ${ }^{108}$.

El último aspecto que se abordó fue el destino de los judíos. ¿Debían dirigirse a países católicos donde pudieran ser adoctrinados en la fe cristiana o simplemente conducirlos al lugar que ellos eligiesen? La discrepancia entre los ministros consultados por la reina se hizo patente desde el principio. Para el cardenal Aragón la cuestión ni siquiera se debía haber planteado, pues ninguna de las alternativas que se elaborasen era viable y además nunca se había formulado en otras expulsiones ${ }^{109}$. El Consejo de Estado votó unánimemente a favor de que fuesen conducidos a la parte que más cómoda resultase a la Corona, sin tener en cuenta otras consideraciones y menos la muy incierta esperanza de que podian convertirse si vivían en un país católico ${ }^{110}$. La Junta a su vez propuso trasladarlos a Liorna; el marqués de los Vélez sugirió también este destino o Génova -recordemos que la primera ciudad pertenecía al gran duque de Toscana, aliado de España por aquellas fechas lo mismo que la república de Génova-; el cardenal Aragón, por último, meses después de su anterior consulta, consideró la posibilidad de que se preguntase a los judios a dónde deseaban trasladarse, si a Amsterdam, Roma, Liorna o Salónica "1". El asunto adquiere un nuevo matiz cuando el conde de Peñaranda apunta

\footnotetext{
107 AHN, Estado, leg. 1.749. Consulta del Consejo de Estado, 20 de julio de 1668 y Consulta de la Junta, 12 de julio de 1668.

108 Ibidem. Consulta del Consejo de Estado, 13 de octubre de 1668; AGS, Estado, leg. 4.128. Bando que en 31 de marzo...

109 Ibidem. Voto particular del cardenal Aragón, 5 de octubre de 1667.

110 Ibidem. Consulta del Consejo de Estado, 15 de marzo de 1668.

"1 Ibidem. Consulta de la Junta, 12 de julio de 1668; Carta del marqués de los Vélez, 13 de junio de 1668; Consulta del Consejo de Estado, 20 de julio de 1668.
} 
que es preciso averigurar si las ciudades o estados estarían dispuestos a admitirlos ${ }^{112}$. Esto suscita una viva respuesta del marqués de los Vélez: no existe motivo alguno para dudar de la acogida que se les dispensará en Liorna o en Génova, "habiendo en dicho lugares juderías formadas con tanto útil de los dueños de las ciudades y repúblicas, y que éste se les aumenta con el acrecentarse esta gente -el comentario, como se puede apreciar, contradice sus anteriores informes acerca del escaso beneficio que los judíos aportan a la Monarquía Hispánica- ${ }^{113}$. Por su parte, la Junta escribe al respecto:

«V.M. no tiene obligación de disponer ni prevenir que sean recibidos los hebreos en las partes a que fueran llevados o quisieren ir, por que ésto es muy accidental y V.M. sólo tiene obligación de atender a la seguridad de la religión y de su plaza y indemnidad de sus vasallos, y si los expulsos eligieren ir a tierras de cátólicos será bien preferirles a las de los infieles, pero V.M. no debe cuidar de si les admitirán o no, y a lo demás que este parecer tiene fundamentos seguros, se apoya también en lo que hicieron el señor rey don Fernando en la expulsión de los judíos y el señor rey don Felipe 3 en la de los moriscos, que no cuidaron las partes a que habian de ir, dexándolo cuando mucho a la elección de los expulsos" ${ }^{114}$.

El 13 de octubre de 1668 el Consejo de Estado resuelve, finalmente, que vayan a «Salónica o otra parte de tierra de cristianos donde ellos les pareciere" ${ }^{115}$, a lo que se aviene la reina, según se desprende del despacho enviado al marqués de los Vélez en 31 de octubre. Por ello, en el bando de expulsión se comunica a los hebros que serán conducidos a donde les ordenare, una vez conferido con sus representantes el lugar más oportuno, para lo cual les convoca el día 1 de abril a las tres de la tarde en la alcazaba ${ }^{116}$.

La orden de salida, aunque inminente, no debió de sorprender a nadie, y al día siguiente de promulgarse el bando la mayoría comenzó a disponer la venta de sus haciendas. Al principio los judios designaron a dos procuradores, Sadia el Hayque y Samuel Zamarro, para que liquidasen en su ausencia los bienes que no pudieran enajenar personalmente. Éstos solicitan al marques de los Vélez la facultad de nombrar una tercera per-

112 Ibidem. Consulta del Consejo de Estado, 20 de julio de 1668 que incluye el voto particular del conde de Peñaranda.

113 Ibidem. Carta del marqués de los Vélez, 23 de septiembre de 1668.

114 Ibidem. Consulta de la Junta, 16 de septiembre de 1668.

115 Ibidem. Consulta del Consejo de Estado, 13 de octubre de 1668.

116 AGS, Estado, leg. 4.128. Bando que en 31 de marzo... 
sona avezada en contabilidad para que les auxilie, lo que fue admitido. Poco después, no obstante, decidieron otorgar poderes a cristianos de su confianza porque no deseaban permanecer más tiempo en el presidio alejados de sus familias, a lo que se avino el gobernador "con toda voluntad por ver de una vez libre esta ciudad de los achaques que le ocasionaba tan mala vecindad" "17. Es muy probable que, al contrario de 10 sucedido en otras expulsiones, los judíos oraneses no sufrieran demasiadas pérdidas en la venta de sus propiedades, cuyo importe pudieron sacar libremente, incluido lo que se abonó por la sinagoga, adquirida por el gobernador para transformarla en iglesia. Avala esta hipótesis la confianza que demostraron tener en ciertos cristianos, tal vez socios suyos en algunos negocios, aunque en este sentido no podemos aportar pruebas documentales que lo confirmen ${ }^{118}$. Tampoco tenemos constancia de cuál fue el trato que en estos días les dispensó la población española y las autoridades militares, pero no es arriesgado suponer que las órdenes del marqués de los Vélez, muy severas al respecto, intimidaran a los violentos, aparte de que ya no tenía sentido agraviarles más de lo que ya estaban. Con todo, en Madrid, o en el mismo Orán, se elevaron voces contra la presencia coercitiva de tantos hombres de guerra en la plaza, innecesarios a juicio de estos críticos, porque con la guarnición habitual bastaba para realizar la expulsión. Tales opiniones son rebatidas por Sotomayor y Valenzuela en los términos siguientes:

«No permite mi celoso cuidado dexar de satisfacer al reparo que consta han hecho algunos discursistas superficiales de que fue demasiada prevención la de esta infantería que pasó de España, diciendo que para gente de tan poco espíritu y valor como los judíos, bastaba la guarnición ordinaria destas plazas. $Y$ aunque en otras partes he tocado esta materia, diré ahora que se hace esta objeción sin reparar en los graves inconvenientes que se podian ofrecer si se llegase a la execución de esta obra con menos prevención. Considere el más atento censurador a qué riesgos se exponía su excelencia si publicada la expulsión, o en términos de sospechada, por una gente tan cavilosa como estos hebreos, sobreviniese algún rebato o invasión de los moros que obligase a salir con la corta guarnición del presidio a la campaña. ¿Qué seguridad podía quedar dentro de los muros? ¿Qué defensa en las casas de los vecinos donde sólo se hallarian niños y mujeres contra unos enemigos sediciosos, irritados, opuestos ya en la última desesperación? El que gobierna debe tener presente todo lo que cabe en la contingencia, y el señor marqués previno,

117 Ibidem. Informe del marqués de los Vélez, 5 de mayo de 1669; Sotomayor ValenzUela, L. J., op. cit., fol. $18 \mathrm{v}$.

${ }_{118}$ De los contactos mercantiles entre cristianos y judíos se hace eco el vicarıo don Pedro Cantera Vaca en su relación de 1630. Ver Jiménez de GreGorio, F., op. cit., pág. 99. 
y debió prevenir, con su prudencia, los accidentes menores que pudo traer el tiempo, siendo cierto que la confiança suele ser enemiga de las resoluciones grandes y que el desear en ellas lo más seguro es abrir el camino a lo mejor" ${ }^{119}$.

El lugar elegido por los expulsados fue Villafranca de Niza, en el ducado de Saboya, ciudad que había sido franqueada por el duque durante diez años para admitir el asentamiento de judíos dedicados al comercio; si reconocían que el lugar no les convenía, entonces pasarían a Liorna ${ }^{120}$. En cuanto al transporte, el gobernador de Orán había prevenido por el mes de diciembre varias saetías catalanas que habían ido al presidio para adquirir trigo con destino a Cádiz y Málaga, concertando con los patronos el flete de las naves una vez desembarcado el cereal en aquellos puertos, pues dudaba de poder hallar bajeles disponibles en Alicante y no convenía contratar unavíos ingleses o franceses por el inconveniente de hacer escala en Argel, con quien estas naciones tienen paz» ${ }^{121}$. El buque genovés del capitán Francisco María Balestrin que condujo las milicias del reino de Murcia le pareció después más seguro que las saetías por ser de quinientas toneladas, capacidad suficiente para acomodar a los pasajeros y sus enseres, y por disponer de artillería con la que oponer resistencia a cualquier ataque corsario, ya que las otras naves ofrecian mayor riesgo de ser abordadas, y aun cuando sólo se perdiera una «se malograba toda la prevención de que no pasasen a Argel por el daño que podía seguirse a estas plazas" ${ }^{122}$. El coste del pasaje corrió a cargo de los expulsados, pero ignoramos a cuánto ascendió ni tampoco si el flete de las saetías que no realizaron al final el viaje repercutió en sus bolsillos o lo sufragó el marqués de los Vélez o la Corona ${ }^{123}$.

A pesar de que en el plazo previsto estaba todo dispuesto para el embarque, éste no se produjo hasta el 16 de abril, cuando el navío genovés pudo aproximarse a la playa - se lo había impedido el mal tiempo-. En la mañana de aquel día se subió a bordo el equipaje y por la tarde lo hizo el pasaje, 476 personas entre hombres, mujeres y niños ${ }^{124}$,

119 Sotomayor y VAlenzuela, L. J., op. cit., fols. 14v-15.

120 AGS, Estado, leg. 4.128. Informe del marqués de los Vélez, 5 de mayo de 1669. Sobre la política de Saboya con los judíos, ver ISRAEL, J. I., European Jewry..., págs. 157-158.

121 AHN, Estado, leg. 1.749. Carta del marqués de los Vélez, 4 de enero de 1669 y Consulta del Consejo de Estado, 24 de enero de 1669.

122 AGS, Estado, leg. 4.128. Informe del marqués de los Vélez, 5 de mayo de 1669; SотоMAYOR Y VALENZUELA, J. L., op. cit., fol. 19.

${ }^{123}$ En la documentación consultada se insiste en que el viaje se ha de costear "de la hacienda de los expulsos" (AHN, Estado, leg. 1.749. Consulta del Consejo de Estado, 20 de julio de 1668).

124 Sotomayor y Valenzuela describe del siguiente modo el embarque de los judios: «Este 
permaneciendo en la plaza un solo judio, Isaac Cansino, que había decidido convertirse al cristianismo -era hijo de Jacob Cansino y había servido de traductor de árabe con el alcalde mayor en asuntos judiciales, pasando luego a ser ayudante de su hermano por nombramiento del gobernador de Orán- ${ }^{125}$. En la noche, el buque partió hacia Mazalquivir a fin de repostar. La salida, prevista al día siguiente, se demoró, sin embargo, a causa del temporal, hasta el 26 de abril, fecha en la que los judios oraneses abandonan definitivamente las plazas ante el júbilo de los españoles que les veían zarpar, ya sin ira, algunos tal vez con pesadumbre, mientras en el interior de la nave el dolor, la amargura, el odio quizás, anidaba en los corazones de quienes a su pesar, y tras siglo y medio de existencia, dejaban con pena sus hogares en poder de los españoles y

día mandó su Excelencia que se pusiese en orden toda la gente de guerra desta guarnición en la plaça de la Alcazaba real, palacio y morada de los sres capitanes generales y a la hora competente se encaminó la marcha en demanda de la marina, tomando la vanguardia, en muy hermosos caballos acompańados de atabales y trompetas, la nobleza del Cabildo y regimiento, representando en forma la dignidad de la muy ilustre y leal ciudad de Orán, y en medio della [...] el estandarte del Santo Tribunal de la Inquisición en manos del reverendo padre fray Hipólito Ortiz, su comisario y prior del convento de Santo Domingo, llevando uno de los cordones de su adorno don Alonso Negrete, regidor perpetuo, por más antiguo y su depositario general, y el otro el licenciado don Pedro Miño, comisario asimismo del Santo Oficio en la ciudad de Villena que se halló huesped en esta ocasión. Después de lo cual, las compañías de infantería de la ordinaria guarnición de este importante presidio [...] con los demás referidos de la extraordinaria y sus oficiales y banderas, siguieron el exemplo y disposición del capitán de caballos don Alonso de Angulo Montesinos, sargento mayor destas plaças, que, habiéndoles ordenado para el efecto, en llegando a la carrera (que es la calle principal desta ciudad y donde en lo mejor della esta la puerta de la juderia), se abrió el escuadrón en dos filas, dexando franca y desembarazada la referida y anchurosa calle para que los hebreos fuesen recogidos y asegurados de todo mal tratamiento, y con mayor decencia para la función que se executó, mandándoles salir de la dicha judería, que fue su mayor dolor y sentimiento. Adelantáronse los Cansinos con sus familias y después todas las demás en confusa tropa, pareciendo a la primera vista mucho más numerosa de lo que se habia considerado, según los cortos principios de que se habia compuesto." Y sigue con la narración: «Recogidos, como digo, en el centro de la ordenada infantería, los fue comboyando por las plazas y calles públicas de la ciudad, cerrando la retaguardia por los mismos pasos el Excelentísimo Sr Marqués de los Vélez [...], con que llegaron a la playa donde estaba esperando en el barquillo (que es el embarcadero della) doce o catorce lanchas bien reforzadas de remeros, en el que fueron entrando por familias para transportarse en el referido baxel que, por su capacidad y grandeza, pudieran ir todos juntos y desahogados, con ser 466 personas las que recibió a bordo, aunque fueran más embaraçados de ropa y de muebles, los cuales vendieron con más codicia de llevarse el dinero de su valor que atención a la falta que después les habían de hacer". Una vez embarcados, escribe nuestro cronista, "siguióse el aplauso popular, la salva de toda la artillería de las fortalezas y castillos destas plazas" (Op. cit., fols. $1919 \mathrm{v}, 19 \mathrm{v}-20$ y $20 \mathrm{v}$ ).

125 Sotomayor y Valenzuela, L. J., op. cit., fols. 20v-21; Baroja, J., Los judios, t. l, pág. 233. Los datos biográficos se han extraído del AHN, Estado, leg. 1.749. Carta del marqués de los Vélez, 22 de octubre de 1666. Sotomayor y Valenzuela menciona que era hermano mayor del rabino Abrahan Cansino y es preciso recordar que éste era hijo de Jacob Cansino. 
sus antepasados yaciendo bajo una tierra que seguramente jamás volverian a pisar ${ }^{126}$.

La navegación no debió de ser muy agradable. Primero, el barco transportaba a los pasajeros y su equipaje - no muy abundante, al parecer-, a la tripulación y con toda probabilidad a un retén de soldados - esto lo había propuesto la Junta en su consulta del 12 de julio de $1668-{ }^{127}$, aparte de las vituallas, artillería y municiones, con lo cual estarian bastante hacinados. Las condiciones higiénicas tampoco serían las mejores, agravadas por el hecho de permanecer anclados en Mazalquivir durante diez días aguantando el embite del oleaje provocado por la tormenta. Por si fuera poco, el viaje duró más de lo normal. El marqués de los Vélez en su informe del 5 de mayo de 1669 calculaba que el navío habría llegado a su destino, aun dirigiéndose a Liorna, pero esto no ocurrió así, pues el duque de Osuna, virrey de Cataluña, da cuenta a doña Mariana de Austria en carta de 18 de mayo de haber arribado a la plaza de Rosas, donde fueron embarcados algunos bastimentos que se necesitaban a bordo para continuar la travesía -en esta misiva se mencionan, por cierto, 450 pasajeros. ¿Fallecieron los demás en el viaje?- ${ }^{128}$. Desconocemos la fecha exacta de la llegada de los judíos a Villafranca de Niza; no obstante, la mayoría no logró desembarcar en la ciudad. Las gestiones efectuadas por Isaac Avigdor cerca del duque de Saboya para admitirlos no tuvieron el éxito que prometían, pues únicamente fueron aceptados los más poderosos, teniendo que desplazarse el resto a Liorna donde, por fin, encontraron el cobijo - así queremos creerlo- que la Corona española les había negado, contribuyendo al crecimiento de esta judería en una nada despreciable proporción y librándose -paradojas de la historia- de la epidemia de peste que asoló a Orán entre 1677 y $1678^{129}$.

126 AGS, Estado, leg. 4.128. Informe del marqués de los Vélez, 5 de mayo de 1669; SotoMAYOR Y VALENZUELA, L. J., op. cit., fol. 20v-21.

${ }^{127}$ La Junta habia propuesto que "lleven la gente necesaria para seguridad de los vasos y que no sean en ellos superiores los expulsos" (AHN, Estado, leg. 1.749. Consulta de la Junta, 12 de julio de 1668 y Consulta del Consejo de Estado, 30 de julio de 1668).

128 AGS, Estado, leg. 4.128. Informe del marqués de los Vélez, 5 de mayo de 1669, leg 2.688. Carta del duque de Osuna, 18 de mayo de 1669.

${ }_{129}$ ISRAEL, J. I., op. cit., págs. 157-158; AMADOR DE LOS Ríos, J., op. cit., pág. 828; Domínguez ORTIZ, A., Los judeoconversos..., pág. 349. Sobre la importancia de la comunidad hebrea de Liorna y su actividad mercantil con el norte de África y el Mediterráneo, ver CASSANDRO, V. M., Aspetti della storia economica e sociale degli ebrei di Livorno nel Seicento. Milán 1983 y TOAFF, R ., "La nazione ebrea di Livorno dal 1591 al 1715. Nascita e sviluppo di una comunità di mercanti, The Mediterranean and the Jews. Banking, Finance and International Trade (XVI-XVIII Centuries), ed. de Ariel Toaff y Simón Schwazfuchs, bar-Ilan University Press, 1989, págs. 271290. De la epidemia de peste en Orán en los años 1677-1678, JiMÉNEz de GREgoRIO, F., “La visita a Orán del vicario Dr. Juan Luengo de Viera en 1682-1683", Hispania, XLVII, n. ${ }^{\circ} 167,1987$, pág. 931. 


\section{ORÁN DESPUÉS DE LA EXPULSIÓN}

Pocas noticias tenemos por ahora de la plaza de Orán tras desaparecer la judería. Lo más relevante, sin duda, es la transformación que experimenta el recinto urbano en apenas un año: se abren calles nuevas para comunicar la aljama con el resto de la ciudad; las casas de los judíos contribuyen a ampliar las de los españoles, que modifican su fisonomía embelleciéndose. El proyecto del marqués de los Vélez de adquirir una porción considerable de dichas viviendas para levantar en su lugar un cuartel donde residiesen los soldados, "de que se necesita mucho", no sabemos si llegó a ejecutarse ${ }^{130}$. Es seguro, en cambio, que la sinagoga fue pronto convertida en ermita, con dos capillas, bajo la advocación del Santo Cristo de la Paciencia, 10 que es muy significativo ${ }^{131}$. La iniciativa fue aprobada tanto por el Consejo de Estado como por el Santo Oficio. En el mes de marzo de 1670 las obras estaban concluidas y los artesanos, según el gobernador, se habían esmerado lo más posible. El 16 de dicho mes se inaugura con todo boato para conmemorar la salida de los hebreos, celebrando su primera misa el titular de una de las capillas, el licenciado Juan Sánchez Solís, "clérigo de muy buen exemplo», habiendo precedido antes una procesión general ${ }^{132}$.

En cuanto al comercio de la ciudad, que los agoreros aseguraban se hundiría tras la expulsión -éste era el sentir de muchos españoles antes de 1669 , como hemos reflejado en páginas precedentes-, el marqués de los Vélez despeja cualquier duda al respecto en su informe a la reina del 5 de mayo de 1669:

"habiendo tan poco tiempo que se ejecutó su salida se ha experimentado to contrario, pues las tiendas no se han disminuido, ocupando cristianos las que ellos tenían, y los mantenimientos han baratado de forma que los carneros valen a dos reales de plata menos que antes, y a este paso todo lo demás, con que me prometo se ha de calificar muy presto la

\footnotetext{
130 AHN, Estado, leg. 1.749. Carta del marqués de los Vélez, 8 de junio de 1667; Sotomayor Y VALENZUELA, L. J., op. cit, fol. $21 \mathrm{v}$.

131 Sotomayor y Valenzuela, L. J., op. cit., fol. 215. Acerca del origen del culto al Cristo de la Santa Paciencia, Caro Baroja, J., Los judíos..., t. Il, págs. 445-446.

132 AGS, Estado, leg. 4.128. Informe del marqués de los Vélez de 5 de mayo de 1669, donde se da noticia de la adquisición de la sinagoga y primeras obras para convertirla en templo cristiano; Consulta del Consejo de Estado, 27 de mayo de 1669 aprobando lo ralizado por los Vélez; Real Decreto de 10 de junio de 1669 confirmando la erección del templo en la sinagoga; leg. 2.690, Carta del marqués de los Vélez, 24 de abril de 1670, informando haber inaugurado la capilla. Ver también Jiménez de Gregorio, L. J., op. cit., pág. 932.
} 
experiencia de que para lo espiritual y temporal ha sido de conveniencia la expulsión" ${ }^{133}$.

Tal comportamiento de los precios responde, desde luego, a una coyuntura muy concreta, no debiéndose ignorar que por entonces el presidio estaba suficientemente abastecido y, por tanto, la abundancia de productos determinaría su menor coste. Para averiguar lo que aconteció en años posteriores habría que estudiar en detalle la evolución de los precios y esto supondría extendernos demasiado. Aun así, pensamos que la presencia o ausencia de los hebreos no afectó en nada al valor de las mercancías, máxime cuando sabemos que el suministro de la tropa era fijado por las autoridades militares teniendo en cuenta el importe de las facturas de los géneros recibidos de la península y que en determinados momentos solían incrementarlos con la complicidad de las justicias locales ${ }^{134}$. Por lo que se refiere al abastecimiento de la población civil, eran los capitulares quienes establecian los precios máximos y mínimos de los géneros, de tal modo que los judíos no podían intervenir en su elaboración. En consecuencia, el informe del gobernador era tendencioso y no respondía a la verdad, o cuando menos ocultaba datos muy significativos que hubieran debido valorarse. Mayor incidencia debió de ejercer en el mercado la abundancia o cortedad de las cosechas y, lo que es igual de importante, la predisposición de los árabes del entorno a vender los cereales a los españoles, condicionada en gran medida por las incursiones de rapiña que de cuando en cuando emprendían los soldados. Por eso, desde Madrid se trataron de impedir las razzias promulgándose diversas órdenes no acatadas siempre y de cuya inobservancia se generó el desabestecimiento de la ciudad, como acontenció en $1564^{135}$. De hecho, durante el gobierno del marqués de los Vélez el Consejo de Guerra nunca aprobó sus incursiones por el riesgo que conllevaban de dejar el presidio casi desguarnecido, pero asimismo por sus repercusiones en el tráfico comercial con los árabes ${ }^{136}$, situación que a partir de 1669 tuvo que experimentar notables cambios al heredar los españoles los contactos que anteriormente mantenían los hebreos, mejor aceptados, y cuya desaparición bien pudiera explicar los períodicos enfrentamientos con los moros

${ }^{33}$ Ibidem, leg. 4.128. Informe del marqués de los Vélez, 5 de mayo de 1669.

134 Braudel, F., op. cit., t. II, pág. 280.

135 Ibidem, págs. 281-282

136 AGS, Guerra Antigua, leg. 2.193. Consulta del Consejo de Guerra, 21 de enero de 1669; leg. 2.189. Carta del marqués de los Vélez, 23 de septiembre de 1668 quejándose de que el Consejo de Guerra le prohiba hacer alardes tuera de la ciudad. 
del interior, tal que el producido en 1682 y en el que fallece el capitán general del presidio, marqués de Algaba.

La hazaña de 1669 contra la judería, ni cruenta ni gloriosa, resultó muy favorable para algunos oficiales protegidos por el marqués de los Vélez. Por lo pronto, y a petición suya, doña Mariana de Austria otorga un hábito militar en cualquiera de las tres órdenes (Calatrava, Alcántara o Santiago) a don Payo Félix Afán de Rivera, caballero de ilustre linaje de la ciudad de Murcia y capitán, por su desvelo en levantar y transportar a Cartagena la milicia de aquella ciudad, sufragando con su dinero el mantenimiento de los soldados. Peor fortuna tuvieron otros dos capitanes, los cartageneros don Alonso de la Jara y Molina y don Alonso González de Sepúlveda, hijo del anterior, pues concurriendo en ambos los mismos méritos se les denegó, al primero, la tenencia general de la artillería de Cartagena y al segundo un aumento de salario (a 160 ducados) por estarse tratando en ese momento la reforma del gasto público, minorando mercedes y reduciendo empleos, aunque se deja al arbitrio del marqués de los Vélez sugerir otras mercedes para ellos ${ }^{137}$. El propio don Fernando Joaquín Fajardo de Requesens y Zúñiga, según ciertos historiadores, logró beneficios personales sustanciosos, pues a comienzos de la década de los años setenta -posiblemente en 1672 - fue nombrado gobernador de Galicia, cargo que permutó con el conde de Aranda, destinado al virreinato de Cerdeña, ya que su objetivo al parecer era aproximarse a Nápoles, meta de sus aspiraciones y que consigue hacer realidad en $1675^{138}$. No obstante, creemos que este honor o premio respondía a la lógica del sistema burocrático de la época y no a otro tipo de consideraciones, aunque tampoco se puedan descartar éstas sin más. Lo mismo cabe decir de la fulgurante carrera de su hijo, don José Fajardo y Toledo: el 4 de enero de 1669 había sido nombrado cuatralvo de las galeras de España y un mes después se le autoriza para gobernar la escuadra en ausencia del capitán general, su teniente o el veedor, pasando en mayo de 1670 a ocupar el cargo de teniente general, si bien en este ascenso tuvo que

137 AGS, Estado, leg. 4.128. Informe del marqués de los Vélez, 5 de mayo de 1669; leg. 2.688. Real Decreto de 29 de junio de 1669 en respuesta a una consulta del Consejo de Guerra de 15 de junio de 1669. La propuesta del hábito militar a favor de don Payo Félix Afán de Rivera es aprobada por el Consejo de Estado de 27 de mayo de 1669 (ibidem, leg. 4.128). La orden de la concesión se encuentra en el leg. 4.128 y está fechada el 14 de julio de 1669 , dirigida al secretario del Consejo de Ordenes. Respecto a la reforma del gasto público en este año, SÁN. CHEZ BELÉN, J. A., "La Junta de Alivios de 1669 y las primeras reformas de la regencia", Espacio, Tiempo y Forma. Madrid, 4, 1989, págs. 639-668.

${ }_{138}$ Maura, duque de, Vida y reinado de Carlos II, t. I. Madrid 1959, págs. 228-229; BarRIos, Feliciano, El Consejo de Estado de la Monarquía Española, 1521-1812. Madrid 1984, pág. 230. 
incidir sin duda su arrojo y valentía, demostrados en numerosas empresas navales ${ }^{139}$.

Queda una pregunta por formular: ¿regresó alguno de los expulsados o de sus descendientes a Orán? La respuesta es negativa. Viene avalada por la propuesta del marqués de los Vélez, aprobada sin vacilar por doña Mariana de Austria, de ordenar a los capitanes generales que le sucedan al frente del presidio - la Real Cédula quedará registrada en la veeduría y contaduría del Consejo de Guerra- de no conceder, bajo ningún pretexto, licencia del tipo que sea a ningún judío para volver,

«sino que V.M. la reservará en sí, representando las razones que hubiera para ella por su supremo Consejo de Estado, como tribunal que está enterado de las que ha habido para expelerlos. Y no me muevo a pedir ésto sin fundamento, porque sé que, en saliendo de este gobierno, ha de haber quién introduzca la plática» ${ }^{140}$.

La seguridad que tenía el marqués de los Vélez de que esto podía suceder aparece confirmada en 1676 cuando el duque de Jovenazo, embajador en Saboya, escribe al Consejo de Estado suplicando que interceda ante la reina con el objetivo de otorgar pasaporte a Aziza Laiche y varios judíos de Villafranca de Niza que desean viajar a Orán para solventar algunos negocios pendientes, de manera que los ministros del Santo Oficio no les molesten en el término de un año o por el tiempo que se declare en el pasaporte. La solicitud no fue denegada, pero tampoco concedida, a lo menos de inmediato. Antes el duque de Jovenazo debía averiguar los motivos concretos que los citados personajes tenian para pasar a Orán y el Consejo de la Inquisición emitir su parecer al respecto. Sólo cuando estuvieran evacuadas estas consultas resolvería lo más conveniente. Mucho nos tememos que entre pesquisas, informes y dictámenes transcurriera tanto tiempo que para entonces ya no estuvieran interesados en emprender el viaje o hubiesen buscado personas de confianza que los representaran. De cualquier modo, en la visita que el vicario don Juan Luengo de Viera realiza en $1682-1683$ no existe una sola referencia a judíos en Orán, aunque únicamente estuvieran de paso ${ }^{141}$.

139 AGS, Guerra Antigua, leg. 3.505. Consulta del Consejo de Guerra, 4 de enero de 1669, 4 de marzo de 1669, 2 de agosto de 1669 y 21 de mayo de 1670.

140 AGS, Estado, leg. 4.128. Informe del marqués de los Vélez, 5 de mayo de 1669.

141 Jbidem, leg. 3.650. Consulta del Consejo de Estado, 22 de julio de 1676 sobre despacho del duque de Jovenazo de 22 de mayo de 1676. 


\section{CONCLUSIONES}

La expulsión de los hebreos de Orán no fue un acto irreflexivo del gobierno español, sino una decisión meditada, a pesar de que no se evaluaron los aspectos positivos de la presencia judía en la plaza. El temor en Madrid a una alianza con los árabes, infundada desde cualquier punto de vista, o con los ingleses y franceses, hipótesis más probable aunque no necesaria, junto con la animadversión de los españoles a todo lo que representaba conductas diferentes, tanto en las costumbres como en las creencias religiosas, y el deseo de algunos oraneses cristianos de ocupar la privilegiada posición de los judios en el ámbito comercial, fueron argumentos decisivos para que se decretara el destierro de la comunidad tras siglo y medio de permanencia en la ciudad, argumentos que también habian estado presentes cuando se planteó la salida de los hebreos en 1492 y de los moriscos en 1609.

Si los aspectos valorados en 1669 apenas difieren de los esgrimidos en épocas precedentes, en la organización de la expulsión se aprecian rasgos peculiares. Ante todo, la Corona adopta una serie de disposiciones orientadas a evitar que se produzcan incidentes que pongan en peligro la seguridad de la plaza, enviando refuerzos militares y armamento, lo que será criticado por ciertos sectores que juzgaban este despliegue excesivo a los fines que perseguía. En segundo lugar, se procura no causar a los expulsados las penalidades que en el pasado habian sufrido quienes se habían visto obligados a dejar por la fuerza los lugares donde nacieran y se criaran. En tercer término, se intenta conducirlos a las ciudades que elijan, siempre que éstas no se encuentren situadas en tierra de moros. Finalmente, se arbitran los mecanismos más adecuados para que en la enajenación de sus propiedades no experimenten daño alguno, vendiéndolas a los precios habituales del mercado. Estos criterios demuestran, así lo creemos, un cambio profundo en la mentalidad de los dirigentes políticos, preocupados por salvaguardar determinados derechos fundamentales del hombre que un siglo antes no eran contemplados, aunque es evidente que se vulnera uno de los más sagrados hoy en día: la libertad de practicar credos y costumbres en cualquier lugar del mundo. 